Max-Planck-Institut für demografische Forschung Max Planck Institute for Demographic Research Konrad-Zuse-Strasse 1 - D-18057 Rostock · GERMANY

Tel +49 (0) 3812081 - 0; Fax +49 (0) 3812081 - 202;

http://www.demogr.mpg.de

MPIDR WORKING PAPER WP 2004-015

MAY 2004

\title{
The compatibility between work and family life - an empirical study of second birth risks in West Germany and France
}

Katja Köppen (koeppen@demogr.mpg.de)

This working paper has been approved for release by: Andres Vikat (vikat@demogr.mpg.de)

Deputy Head of the Laboratory of Contemporary European Fertility and Family Dynamics.

(C) Copyright is held by the authors.

Working papers of the Max Planck Institute for Demographic Research receive only limited review. Views or opinions expressed in working papers are attributable to the authors and do not necessarily reflect those of the Institute. 


\title{
The compatibility between work and family life - an empirical study of second birth risks in West Germany and France
}

by

Katja Köppen

\begin{abstract}
In this study, we compare second birth risks in France and West Germany using data from the Family and Fertility Survey (FFS). Second birth risks in France are higher than in West Germany and we investigate whether this phenomenon relates to different institutional constraints regarding the compatibility between work and family life. Considering that education is a good indicator for higher career and income prospects, one would assume that highly educated women encounter low fertility rates in a society that makes it hard to combine both domains. Our results, however, show that second birth risks are higher for highly educated women than for women with lower education in both countries. Nevertheless, the positive effect of women's education on second birth risks is strong and stable in the case of France only. In West Germany, the positive effect is a weak one and it weakens even further after controlling for the eduaction level of the partner. In France, the strong positive effect of women's education on second birth risks remains unchanged, even after controlling for the partners' characteristics and other control variables. Our conclusion is that since in France the compatibility between work and family life is relatively high, highly educated women turn their education into work opportunities and income. In West Germany, where work and family life are rather incompatible, women often have to make a decision between an employment career and motherhood as two exclusive life options. In such a situation, it is primarily the partners' economic situation that influences fertility.
\end{abstract}




\section{Introduction}

Since the last three decades, female labor-force participation has been increasing in most European countries. At the same time, a decline in childbearing rates has been observed. Often a connection is made between these two developments: The increase in female activity rates is hypothesized to have led to a reduction in fertility. However, there have always been pronounced differences in the labor-market activity of women in Europe and in recent years, a new pattern seems to have emerged. In some countries where female labor-force participation is high, birth rates are higher, too, than in the rest of Europe (Brewster and Rindfuss 2000, Adserà 2004). To what extent, then, does a connection exist between these two developments?

Female emancipation and the associated changing role of women in society led to an increase in female employment and rose women's awareness of life perspectives other than that of "being a mother and housewife". Some countries actively supported and encouraged individual female autonomy and worked towards achieving compatibility between work and family life. In the Scandinavian countries, for example, female employment rates increased as a result and the number of children remained higher than in other countries. Other countries did not react to the social changes that emancipation brought in its wake, and this made it harder for women to combine both life domains. A large part of women stayed childless or opted to have a small family to avoid the strains involved in combining the two mutually exclusive roles of being a mother and a full-time employee (for example in the Southern European countries).

In this paper, the two neighboring countries West Germany and France are examined. The literature classifies West Germany and France as conservative welfare states (Esping-Andersen 1990). However, both countries differ in many respects in terms of demographic development. For several decades, birth rates in France have been higher than those in West Germany: A West German woman in the year 2000 had on average 1.38 children; this compares to an average of 1.89 children for French women (Council of Europe 2001). The second difference concerns female employment rates. They, and especially the maternal ones, are higher in France than in West Germany. Even children under three years of age do not seem to be a reason for interrupting labor-market work. Additionally, female full-time employment is much more 
common in France than in Germany. Finally, one can observe much higher rates of childlessness for West German women, especially for those with higher education.

The aim of this work is to find possible reasons for the differences mentioned above and to discuss them theoretically and empirically. To what extent do the social and institutional conditions account for the differences between the two countries? Is it easier to combine work and family life in France than it is in West Germany? Can we find empirical evidence for this?

We will limit the analysis to second birth risks for two main reasons. First, French family policies have always had a stronger pro-natalistic orientation than West German policies. For this reason, it is particularly interesting to compare higher-order fertility in France and West Germany. Second, French family policies are supportive as regards the compatibility between work and family life, whereas German family policies tend to favor traditional family types, that is, the male partner is employed full-time, while the mother reduces her working hours to care for the children. The effect of education is of special interest here. Some authors argue that highly educated women in West Germany either stay childless or have more than one child. This is known as the "polarization" of family forms (Huinink 1989, 1995, 2002; Grundmann et al. 1994). Under the existing incompatibility of work with family life, a great proportion of West German highly educated women stays childless because they opt for a career instead of a family. The rest accepts work and childbearing incompatibility and concentrates on family life. To France, by contrast, "polarization" of such kind does not seem to apply. In this context, the second birth is especially worthwhile of study. Education may have a positive effect on second birth risks for highly educated West German women who are already mothers. And what about France - do pro-natalistic policies support larger families and can highly educated French women benefit from policies that promote the compatibility between work and family life?

The paper is structured as follows: In the next section, we go into some demographic and socio-economic details - what has changed during the last decades, what are the similarities, what are the differences? In Section 3, we provide an overview of some of the most important public policies that influence the childbearing process, concentrating on the availability and quality of public childcare arrangements, 
parental leave schemes and monetary support for families. In Section 4, we present our theoretical framework, focussing on the economic view of demographic behavior (e.g. Becker 1993, Ermisch 1988, Mincer and Polachek 1982) and some aspects of Welfare State Theory (e.g. Esping-Andersen 1990, 1999; Gornick, Meyers, Ross 1997; Anttonen, Sipilä 1996). We will also present our main hypotheses here. In the empirical part, Sections 5 and 6, the data sets and variables are introduced and the influence of education on the transition to second birth will be analyzed by using event-history techniques and estimating a piecewise-constant model. 


\section{Demographic and socio-economic changes since 1960}

In West Germany, an increase in the number of singles and childless couples has been observed since the mid-1960s. The birth of the first child has been postponed and the proportion of families with more than two children has decreased (Huinink 1995). The number of divorces has increased as well as the number of non-marital unions. However, the share of extra-marital births is not very large in comparison to other European countries: Only $18 \%$ of all children were born out of wedlock in 1999. This compares to more than $40 \%$ of all new-born children in France who had no married parents (Le Goff 2002). The German Total Fertility Rate is one of the lowest in the world. In the 1970s, it leveled off at around 1.4. The Completed Fertility Rate is also very low: The average number of children for women who were born in 1965 is estimated to be 1.47 per woman (Council of Europe 2001). The very high rate of childlessness is a special German characteristic: $25 \%$ of women born in 1960 will presumably stay childless (Kreyenfeld 2002). The more educated the women are, the more likely it is that they will forego childbearing - around $40 \%$ of all highly educated women are expected to remain childless (Kreyenfeld 2004).

We find some similar but also some different characteristics for France. French women postpone childbearing also, the average age at firth birth has increased from 24 in the 1970s to 27.4 in 1995 (Toulemon 2001). Divorce rates have increased, too, and the number of families with more than three children has declined. However, the numbers of third births are still quite high in France when compared to West Germany. This and the fact that nine out of ten French women become mothers provides France with the second highest fertility in the European Union - only Ireland has higher birth rates (European Commission 2002). Since 1975, the TFR remained more or less stable at 1.8 children per woman. Cohort fertility is even higher, the 1965 birth cohort has on average 1.99 children, which comes close to the replacement level of 2.1 children per woman (Council of Europe 2001). What is more, the birth of a child is not directly related to the marriage of its parents. Cohabitation seems to be an accepted way of living. It appears that cohabitation is not only a phase of transition but also an increasingly accepted way of life in France: Also people in higher ages increasingly tend to cohabit (Klein et al. 2002). Childlessness is less pronounced than it is in West Germany - only around $10 \%$ of women born between 1950 and 1960 stayed childless (Toulemon 2001). 
The development of female labor-force participation differs remarkably between the two countries, too. In both countries, the extent of female market work has been increasing since the early 1960s, especially that of married women. In 1999, almost $70 \%$ of all married West German women in the age group 25-49 were employed, 40 $\%$ of them worked part-time (Eurostat 2001). Almost half of the women with parttime jobs worked less than 20 hours a week (Schwarz 2001). If there is a child under three years of age in the household, the employment rate falls to $60 \%$. French women, by contrast, are employed relatively continuously, independent of the marital status or the presence of children. Around $80 \%$ of all women aged 25-49 are economically active; most of them work full-time (Eurostat 2001). This can be seen from Figure 1, which displays employment patterns of women based on own calculations with data from the Family and Fertility Survey (FFS). While West German mothers are mostly not employed, French mothers remain in the labor market. For women without children, almost no difference can be noted.

Figure 1: Activity Status of West German and French women, with and without children. West Germany 1992 (cohorts 1952-72), France 1994 (cohorts 1944-73)

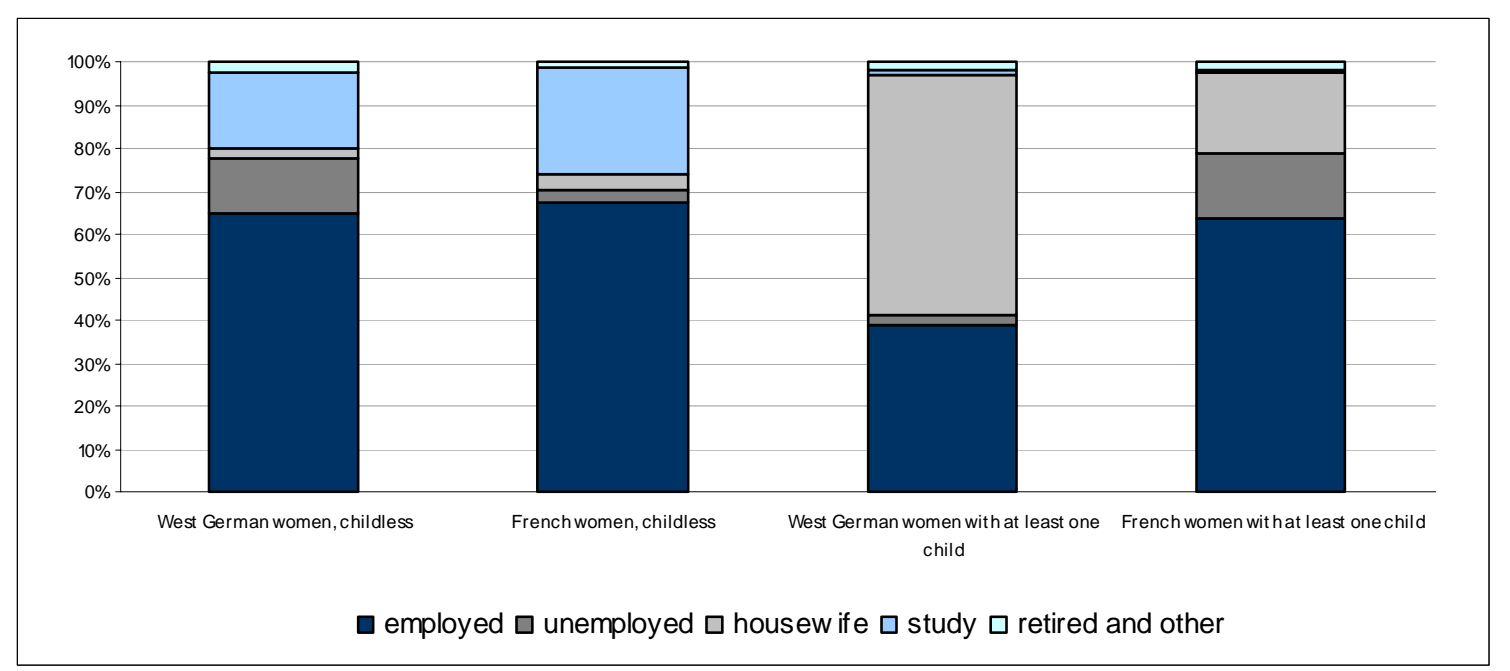

Source: West German FFS (1992), French FFS (1994)

In the next section, we discuss whether the high maternal employment rates in France as well as the high French fertility rates are an indication of greater compatibility between work and family life and, if so, whether this can be theoretically explained. First, the institutional and cultural background in both countries will be examined in closer detail. Second, the findings will be embedded into a theoretical framework, particularly addressing the connection between education and childbearing. Is higher education an obstacle for having children? 


\section{The institutional framework}

Some of the most important aspects of the institutional framework in France and West Germany - public childcare, parental leave schemes and monetary support - will be described in this section to clarify whether they are part of an explanation that accounts for the different fertility and labor-market patterns.

\subsection{Public childcare}

The childcare system in France is well developed in that it facilitates the combination of family duties with employment. Children aged three to six are covered $100 \%$ by child care owing to the French pre-schooling (école maternelle) system, which is part of the education system and free of charge. The provision rates for under-3-year-olds are higher than those for infants in the German Kinderkrippen (Becker 2000). In France, $9 \%$ of these children have places in so-called crèches, $15 \%$ are looked after by a licensed childminder and $3 \%$ by a private nanny. In West Germany, only $3 \%$ of the under-3-year old have a place in the Kinderkrippe (Sell 2002). Children between three and six years of age have a child care coverage that is almost complete, however, often entailing only a few hours of care per day without lunch and care in the afternoon. Only one fifth of all Kindergarten places offer full-time care (Hank et al. 2003). This makes even a part-time job for West German mothers hard to realize. Children in compulsory education attend school all day in France, while in Germany they attend Halbtagsschulen, which usually finish between 1 and 2 o'clock p.m. Only $6 \%$ of all West German school-aged children have a place in the so-called Horte in the afternoon, the others are looked after by their parents, grandparents or private initiatives (Kreyenfeld et al. 2002).

The differences in childcare provision in both countries are not only the result of different family policies but also of different popular attitudes towards caring for small children. The majority of the West German women are convinced that a child under three years of age mainly needs its mother to grow up emotionally stable and that any separation during that period is traumatic for the child (Fagnani 2002). This may also explain the low employment rates for West German mothers with smaller children (Figure 2). French mothers, by contrast, do not think that female employment is harmful to young children: Only $16 \%$ do not wish to take up a job when their 
children are below school age; this compares to 34\% in West Germany (Fagnani 2002). The maternal employment rates in Figure 2 reflect these attitudes. In France, a small child does not seem to be a reason to interrupt market work: $80 \%$ of the mothers with one child below age three are employed, the proportion decreases when they have to take care of three or more small children. In West Germany, the employment rate for mothers with one child below age three is $25 \%$ lower than in France but increases when the child can attend the Kindergarten. However, it never reaches the level of French mothers.

Figure 2: Employment rates of West German and French mothers by number of children (aged under 25) and age of youngest child (in \%), 1997

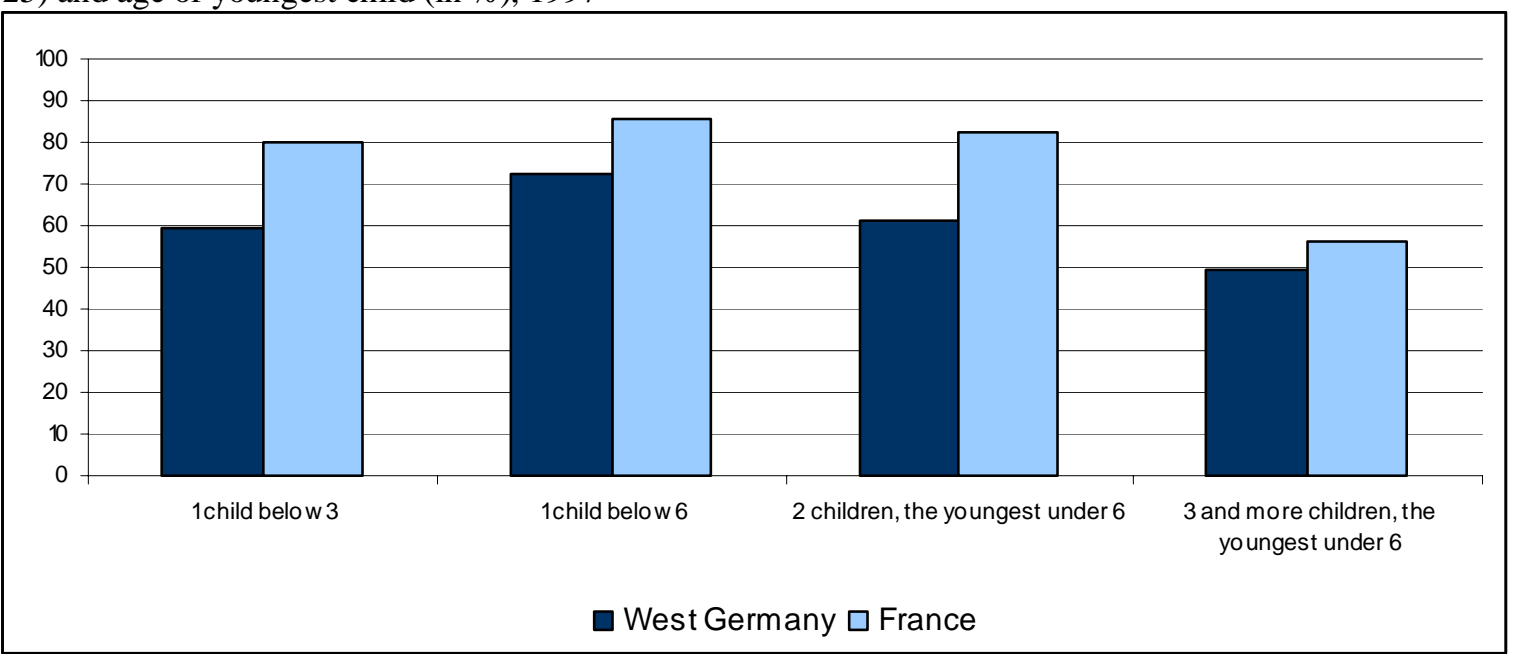

Source: Eurostat, Labor Force Survey 1997 in: Reuter 2002, p. 15

\subsection{Parental Leave Schemes}

Parental leave is geared towards enabling parents to keep their salary and job while caring for young children. Especially in connection with flexible working hours and on-the-job-training during parental leave, this gives women and men the opportunity to care for their small children without loosing contact to their jobs.

Parents in West Germany are entitled to parental leave until the child is aged 3. They receive childrearing benefit during most of that time (Erziehungsgeld), which is income-related and at most $307 €$ per month (for two years) or $460 €$ per month (for one year). It is not intended to be an income replacement but serves to acknowledge childrearing. Under parental leave regulations, West German parents can work parttime (until 2001 a maximum of 19 hours a week, 30 hours since 2001) and both can take parental leave at the same time. Nevertheless, only about $2 \%$ of the fathers 
entitled take this option. In France also, the majority of persons using parental leave are female. French parents are able to work part-time as well and likewise can take time off together. In France, fathers are entitled to take a two-week long paternity leave, which is fully compensated. Child-rearing benefit (APE - allocation parentale d'èducation) is paid from the second child onwards. APE is dependent on work experience previous to parental leave- the person who wishes to take leave must have been in gainful employment for at least two years within the five years preceding second birth (10 years before the third birth). It is paid independently from prior income $(484,97 €$ per month). As a result, the majority of the recipients are women. This is because they earn less money on average than men do. It is economically of greater benefit to do without a minor income than loosing the higher income. Especially women with low qualifications and relatively low earnings or unemployed women do take parental leave in France (Reuter 2002). APE was first introduced in 1994; before then, it was only paid to parents with at least three children. This clearly reveals the pro-natalistic aim behind this policy.

\subsection{Monetary support of families}

Apart from parental leave entitlements, other monetary benefits that supplement family income are available. They reduce the costs of having children and are paid as transfers (child benefits) or tax reliefs.

Child benefit in France (allocations familiales - AF) is paid from the second child on. It is paid until the $20^{\text {th }}$ birthday of the child, provided that his or her income does not exceed a particular limit. The amount of benefit increases with the number and age of children. Needy families in France can also receive allocation pour jeune enfant (APJE) if the first child is under 3 years of age. In Germany, child benefits are paid from the first child on. It is paid until the child reaches age 18 or is still in training (until age 26) provided that his or her income does not exceed a particular limit, too. Apart from child benefit, tax reliefs also support families with children. German parents, especially those with a higher income, benefit from the so-called Kinderfreibetrag - this tax allowance is charged against the child benefit drawn and is paid instead of child benefit. Besides, the German system especially supports married couples, with or without children. Tax relief in Germany is particularly high for those married couples in which one of the partners is not employed or in part-time work 
(Ehegatten-Splitting). It therefore favors one-earner-families and strengthens the male breadwinner model. Besides, married housewives are automatically co-insured by the health insurance of their partners, and this also encourages women to stay at home and rely on their partner's earnings. The French tax system, too, favors one-earnerfamilies, however, only if there are no children in the household. Childless couples receive the highest tax relief when one of the partners is not involved in gainful employment or works part-time. French couples with children benefit from the system of family splitting: The tax burden is reduced in relation to the number of children and it does not matter whether one partner is employed full- or part-time (Dingeldey 2000).

\section{Theoretical considerations and hypotheses}

Classical micro-economic rational choice theory, as represented by the New Home Economics, postulates that the rise in female labor-market participation lowers fertility (Mincer and Polachek 1982, Becker 1993). The gender-specific division of labor is seen as economically beneficial (Becker 1985). Accordingly, carrying out parenting tasks is a rational choice of the person with the lowest market wage. This is usually the woman since she tends to have a lower income than her male partner does. With growing labor-market orientation of women over the last decades, female employment opportunities and wages have risen. This led to increasing opportunity costs of children: The time spent with caring for and upbringing children could be used for gainful employment. Staying at home meant a loss of potential income and human capital accumulation. Assuming that the education level of a woman reflects her career and income possibilities, a negative correlation between female education and fertility is expected.

However, for some countries the opposite pattern has been observed. In the last years, a positive effect of female education on childbearing has been noted, especially for the Nordic countries (e.g. Hoem and Hoem 1989, Kravdal 1992, Hoem 1993, Oláh 1996). One explanation could be that a higher income also implies higher resources that can be allocated to a larger family. Moreover, highly educated parents are in a better position to make use of private childcare because they enjoy higher wages and possibly flexible working hours, too (Hoem et al. 2001). This "income effect hypothesis" (Kreyenfeld 2002) indicates that family and working life can be made 
compatible. This applies particularly to Scandinavia or even France because both countries have generous family support schemes and full-time day care is well developed. But it is unlikely that such considerations matter for West Germany, where no such encompassing policies exist.

Welfare state theoreticians have explained the intra-country differences in fertility and employment behavior with the different attitudes of states towards working mothers (e.g Langan/Ostner 1991, Lessenich/Ostner 1995, Gornick/Meyers/Ross 1997, 1998, Anttonen/Sipilä 1996, Esping-Andersen 1999). By comparing institutional structures and public policies, they showed that state-aided measures help women to realize their potential income without foregoing their desire for children. Family policy as part of welfare state policies has an influence on the employment rates of mothers and may disburden them from some costs that go along with raising children. As has been shown in the comparison of the institutional frameworks, West Germany and France differ greatly in the extent to which the state supports families and the institutional framework is shaped. In West Germany, social and economic conditions favor the role of the male breadwinner and the female housewife while women in France are encouraged to return to the labor market after childbirth.

It seems that France provides greater opportunities to have a gainful employment and raise children. French women are more likely to continue work after parental leave since they can make use of the generous supply of child care arrangements. Especially after the birth of a first child, French women are expected to go back to the labor market: There are hardly any monetary incentives or state aided measures that support the model of the female housewife during that time. Public day care that is either free of charge or supported by the state and all-day schools additionally facilitate French mothers' employment. From the perspective of the economic theory of the family, French mothers encounter lower opportunity costs of childrearing compared to their West German counterparts. Even when raising and caring for children, they can keep their job and their income.

In West Germany, opportunity costs of childbearing are higher since the institutional and social conditions do not encourage the compatibility of family with working life. Especially well-educated women with higher income prospects therefore either stay childless or resign from their working career in favor of a family. In view of the very low public child care provision in West Germany, highly educated and better paid 
women are faced with making a decision between giving up employment and caring for a child or keeping their income but abstain from having children.

Huinink (2002) argues that the special German institutional framework leads to a "polarized" fertility pattern among highly educated women. He expects such a pattern to prevail in all countries, where maternal employment and childrearing are not compatible. Some countries (such as Germany) have promoted female emancipation, for example, by providing greater opportunities for women to participate in higher education, but did not introduce sufficient measures to strengthen compatibility between work and family life. Particularly in these societies, highly educated women with good income prospects suffer from decision conflicts. If they opt for a career, they will mostly need to forego the benefits from having children. If they decide for a family, they accept the high opportunity costs of a foregone labor-market career or at least have to reduce their working hours drastically. The latter group will be rather selective - they accept the opportunity costs that arise from having children and devote themselves to family life, probably even having a larger family than on average. The consequence is a polarization of highly educated women between childlessness and having a larger family. Huinink (2002) found empirical evidence for this phenomenon. He analyzed the distribution of family size by education degree in various countries with the Family and Fertility Survey. Looking at the cohorts born 1950 and later, he finds that highly educated West German women either stay childless or have two children.

With regard to our observation on the second child, we conclude the following:

In the West German context, highly educated women with one child are a rather select group. They manifest high preference for children by having a first child despite high opportunity costs of childrearing. Additional opportunity costs for the second child are only minor. One would therefore expect highly educated women to stay either childless or have two or more children. As a result, we expect the second birth risk for West German mothers with higher education to be higher than for women with a lower degree ${ }^{1}$.

In societies with greater opportunities of child caring outside the family, the decision in favor of a family and labor-force participation of both partners is made easier. Therefore, the group of highly educated mothers in France should not be as selective

\footnotetext{
${ }^{1}$ For the purpose of this paper, the term "degree" acts as an umbrella term for any kind of schooling leaving qualification.
} 
as in West Germany. For that reason, we do not expect elevated second birth risks in France. However, there are other potential reasons why in France also we may find that higher education increases second birth risks. Against the background of the institutional framework, French women are encouraged to return to the labor market after childbirth. Especially highly educated women may be expected to do so because they encounter higher opportunity costs of childrearing. One assumption is that they try to space their births closely together to return to work as soon as possible and reduce the costs they have while they are out of employment (Ní Bhrolcháin 1986; Kreyenfeld 2002). This means that they have their second child earlier than other women do, and this increases the second birth risk and indicates the existence of a timing effect. Another possible explanation is that they have a higher income and are therefore in a better position to support a larger family. We therefore also expect French women with higher education to have a higher second birth risk than their counterparts with lower education degrees.

In order to analyze the transition to the second child and test our hypotheses, we use the Family and Fertility Survey (FFS) for both countries. The following section focuses on an introduction of the data sets and an explanation of the variables we use, together with some descriptive analyses.

\section{Data and Method}

\subsection{The Data Set}

The study uses data from the "Family and Fertility Survey (FFS) in Countries of the ECE Region". The FFS was conducted in the 1990s in selected member states of the United Nations Economic Commission for Europe (UNECE). 24 countries joined the FFS project. As of 1992, a standard FFS questionnaire has been available. The standardized FFS data files are mainly used for comparative research on fertility and family issues. We use the French and the West German standard record files. The survey was conducted in West Germany in 1992 and in France in 1994. In West Germany, 5,036 respondents were interviewed (2,024 men and 3,012 women). This compares to 4,885 respondents in France (1,941 men and 2,944 women). 
The advantage of the FFS is that its design is comparable and retrospective - we have internationally comparable information on family and fertility histories, education, employment and partner characteristics. Unfortunately, not all countries closely followed the guidelines for the standard record file. For this reason, we do not have data sets that are $100 \%$ comparable. For example, the French survey does not include complete employment histories, although the West German does. To achieve greater compatibility, we therefore only used a fixed but comparable covariate for the employment status. Another problem is that the French survey contains an overrepresentation of lone-parents or blended families. Of the 5,000 households that were interviewed, 1,411 had a child who was living with only one or neither of his or her parents. A random sample would have contained only 560 such households (Toulemon, Guibert-Lantoine 1998). Because of this, we used a given weighting factor to control for the bias.

The French FFS includes foreigners while the German survey only contains German nationals. We would have excluded the foreigners from the French sample to make both data sets more comparable, however it is not possible to identify foreigners in the French standard record file. We analyse German women born between 1952 and 1972, for France we have respondents born between 1944 and 1973. The sample consists of women who had at least one child and were at risk of having a second child. The total sample size (after cleaning our data, see Tables 1 and 2 in the Appendix) is 1,293 for Germany and 2,063 for France. Second births totals 751 in Germany and 1,400 in France.

\subsection{Method}

The event under study is the occurrence of a second birth. We apply an event-history analysis, as it is suitable for studying events that occur during the life course. Multiplicative intensity-regression models are estimated to measure second birth intensities $(\mu)$ for West German and French women. These intensities are influenced by various covariates, such as the education level of the women or the age at first birth. The start of the process time is the date of birth of the first child. The process ends with the second child's date of birth. It may also end with age 45 or at the date of interview respectively. 
The baseline hazard (basic time factor) is the duration since the birth of the first child. We use a piece-wise constant model i.e. the basic time factor is defined as a categorical variable - the risk is constant over each set of time intervals. The other covariates are categorical, too. Our main analysis includes five time-fixed covariates and two time-varying covariates.

The model with our main effects can be written as follows:

$$
\mu(t)_{i j k l m n o p}=a_{i(t)}+b_{j}+c_{k}+d_{1}+e_{m}+f_{n(t)}+g_{o(t)}+h_{p}
$$

where $a$ represents the effect of the time factor (duration since birth of the first child in months) and $i(t)$ denotes the intervals in which the baseline hazard is assumed to be constant (0-12, 13-24, 25-36, 37-48, 49-72 and 73-120²).

Factor $b$ is the effect of age at first birth (time constant),

Factor $c$ the effect of the highest education level of the respondent (time constant), Factor $d$ the effect of the highest education level of the partner (time constant), Factor $e$ the effect of employment (time constant), Factor $f(t)$ the effect of marital status (time-varying), Factor $g(t)$ the effect of calendar time (time-varying) and Factor $h$ the effect of residence (time constant).

The software used for modelling is Rocanova (version 2.0), developed by Sten Martinelle, Statistics Sweden 1996. The construction of the variables, the editing of the data set and also some modelling was done with the help of STATA.

\footnotetext{
${ }^{2}$ For France we have an additional time interval, covering a $7^{\text {th }}$ interval: 121-180 months after first birth.
} 


\subsection{Variables}

Our model contains five time-fixed covariates, two time-varying covariates and the baseline hazard. For West Germany, there are two more variables which were not available for France because of data restrictions: residence until age 15 and employment status as a time-varying covariate.

Next, we introduce these variables and discuss their possible influences on the birth of the second child.

\section{The influence of the highest level of education of the respondent}

The education degrees in the data sets were coded with the help of ISCED 76 (International Standard Classification of Education). We classified them into three groups:

1. no or low degree $=$ no degree or at least in education until age 16 ,

2. medium degree $=$ vocational degree (three years vocational training after secondary school) or Abitur (three years of education with general qualification for university entrance),

3. higher degree $=$ all university degrees (or technical colleges).

We used the variable highest level of education as a time-fixed covariate. An anticipatory analysis is mostly considered to be inaccurate because it can bias the results (Hoem 1996). If we want to examine events that are dependent of the education degree throughout the life course, it is inappropriate to use time-fixed education degrees. The education degree measured at the date of interview may not be identical to the degree the women had when she was at risk of a particular event. In other words, using education as a fixed covariate in the process of fertility may produce biased results. For the analysis of second birth risks, it is nevertheless relatively uncomplicated to use education as a fixed covariate. This is because most of the women completed their education before the birth of their first child, while they were not at risk of a second birth yet. This also applies to West Germany and France. Only very few people were still in education after first childbirth, so there is not much danger of an anticipatory analysis, using education as a fixed covariate (see Figure 3 in the Appendix).

We expect a positive correlation between education and the birth of a second child, however, the argumentation is different for both countries. In France, the income 
effect should be stronger than the substitution effect: highly educated women have greater financial resources to invest in a larger family. Besides, highly educated women in France may intend to return to work as soon as possible and therefore space their births close together in order not to loose contact to work after first childbirth (Ní Bhrolcháin 1986). This should increase second birth risks as well. This argument does not apply to West Germany, however, where social and institutional conditions hamper the compatibility between maternal employment and childrearing. The "polarized" fertility behavior of women with a university degree highlights these difficulties: Highly educated women who decided in favor of a family despite the high opportunity costs of childbearing have a much stronger family orientation than other women with one child and they should therefore give birth to a second child more often.

\section{$>$ The influence of age at first birth}

Education influences fertility also indirectly. Assuming that highly educated women have their first child later in life than their counterparts with lower qualifications because they are longer in education and rarely have children during that time (Blossfeld, Huinink 1989, 1991) - one can hypothesize that they have their second child shortly after the first one because of biological limitations (Kreyenfeld 2002). With growing age medical problems arise. Older women cannot delay childbearing for a long time. This should increase second birth intensities.

\section{$>$ The influence of the partners' highest education level}

Women with higher education more often have partners with a university degree. Educational homogamy is especially pronounced among the well-educated (see Figure 4 and 5 in the Appendix). One can assume the existence of a positive correlation between the education level of the partner and second birth. Men with higher education mostly enjoy a higher income. Especially in West Germany, where one-earner-marriages are more frequent than in France, the man should be able to invest his income into a larger family. Particularly the education of the partner should therefore influence the higher transition rates to a second child in West Germany. French women, by contrast, may support a larger family more autonomously.

\section{The influence of the employment status}

Because of data restriction, the employment status for both countries was only measured as ever or never employed. Women who have never been employed should be very family-orientated. This group should have a higher second birth risk than 
those women who have ever been employed (more than three months of gainful employment). Especially women with higher education who were never employed may have a stronger orientation towards family life and as a result have high second birth intensities.

Besides, the West German FFS offered the possibility of generating a time-varying variable that measures the employment status after the birth of the first child. Since a pregnancy mostly leads to the interruption of employment, for this part of the analysis we subtracted 9 months from the birth date of the second child - at this time most of the women surveyed did not know that they were pregnant and the decision to keep or quit their job should be made independent of the decision to have a second child. This covariate is a combined variable that measures whether a West German woman was in employment any time after the birth of her first child or not. It shows the strengths of her labor-market attachment after the decision to found a family. It should be stronger if she worked any time before and after the first child or if she started work after the birth of the first child and did not interrupt her employment. Those women may become a mother for a second time less often than women who never worked or interrupted employment after the birth of the first child. Being out of employment after the first birth includes those women, who stopped working some time after the first child or before the birth of their first child and did not continued with work afterwards. Those who have never been employed - neither before nor after the first child - form a third group.

\section{$>$ The influence of the marital status}

We assume that marriage and having children are still closely connected in both countries. In the light of the high number of children born out of wedlock in France, one can assume that French women who marry are a very selective and probably more traditional group than their unmarried contemporaries. Their second birth risk should be higher than for other women. In West Germany also, with its strong support for married couples, second birth risks of married women should be higher. Women who have married more than once should get a second child more often than women of first-order marriage. The desire to have a child with the new partner should be high. Being divorced, widowed or single affects childbearing negatively. 


\section{The influence of calendar time}

State support of families and incentives for childbirth (e.g. extended parental leave or raising benefits) may lead to an increase in childbirths. However, the inclusion of this variable into the analysis is somewhat problematic. This is because not only changes in family policies but also the general economic situation and social dispositions are measured and it is difficult to keep these factors apart. Hypotheses on the influence of calendar time are therefore hard to predict. If there are significant effects, they should exist for West Germany after 1986 (when paid parental leave was introduced) and France after 1994 (paid parental leave was extended to apply to the second child). Unfortunately, this effect is not measurable for France because the survey was conducted in 1994.

The grouping of calendar time was chosen on the basis of various family policies to find possible effects that could be caused by changes in the institutional framework.

These measures are presented in Table 3:

Table 3: Family policy measures in Germany and France

\begin{tabular}{|c|c|c|c|}
\hline $\begin{array}{l}\text { Policy } \\
\text { period }\end{array}$ & Germany & $\begin{array}{l}\text { Policy } \\
\text { period }\end{array}$ & France \\
\hline 1975 & $\begin{array}{l}\text { Child benefit reform: income-independent } \\
\text { child benefit for all children }\end{array}$ & 1972 & $\begin{array}{l}\text { Income-dependent childcare subsidy } \\
\text { (AFG), introduction of pension claims } \\
\text { for times of childcare }\end{array}$ \\
\hline 1979 & $\begin{array}{l}\text { Introduction of maternal leave ( } 6 \text { months) and } \\
\text { maternity benefit until max. } 750 \text { DM per } \\
\text { month }\end{array}$ & $1976-78$ & $\begin{array}{l}\text { Introduction of unpaid maternity leave, } \\
\text { lone-parent-support (APJ), support for } \\
\text { families (CF): income-dependent social } \\
\text { benefits, official recognition of } \\
\text { childminding as an occupation }\end{array}$ \\
\hline 1983 & $\begin{array}{l}\text { Cuts in maternity benefit to max. } 510 \mathrm{DM} \text { per } \\
\text { month }\end{array}$ & $1982-83$ & General shortage in the national budget \\
\hline 1986 & $\begin{array}{l}\text { Introduction of paid parental leave, max. } 600 \\
\text { DM per month }\end{array}$ & $1984-86$ & $\begin{array}{l}\text { Increased support for lone parents, } \\
\text { income-independent child benefit from } \\
\text { the third child on (APE), childminders } \\
\text { support (AGED) }\end{array}$ \\
\hline 1990 & Allowable deduction for home helps & $1991-93$ & Tax reduction for home helps \\
\hline 1992 & Increase of child benefit and Kinderfreibetrag & 1994 & $\begin{array}{l}\text { Extension of APE to second children, } \\
\text { possibility to work part time }\end{array}$ \\
\hline
\end{tabular}

\section{The influence of the place of residence}

Living in a rural area probably increases second birth risk. The more traditional life in the countryside and the potential desire to offer children a healthier and more secure environment than the city would offer may lead to higher second birth intensities. Also, growing up in a rural area may increase the intensity of second-order births. Unfortunately, the variable residence until age 15 was only available for West Germany. 
In Table 4, the distribution of the fixed covariates in absolute and relative numbers is displayed. As mentioned before, we used weights for the French sample because of the oversampling of lone mothers and blended families. We therefore show the unweighted and the weighted sample size in the following tables in order to exemplify how the weights change the distribution of the sample. This comparison suggests that one should prefer to use weights because of the overrepresentation of lone mothers that may otherwise exist. They are a select group who are probably younger and have lower education degrees than other women do. If we ignore this effect, the results may be biased. Therefore, we decided to use weights for France not only in our descriptive analysis but also later in the multivariate analysis.

After weighting the French sample, we find that the proportion of women who do not have a partner living in the household decreases from $26 \%$ to $11 \%$ - an example showing that using weights is reasonable and necessary.

Table 4: Distribution of respondents according to the various levels of the time fixed covariates. Absolute and relative number of respondents

\begin{tabular}{|c|c|c|c|c|c|c|}
\hline \multirow[b]{2}{*}{ Variables } & \multicolumn{2}{|c|}{ West Germany } & \multicolumn{2}{|c|}{ France } & \multicolumn{2}{|c|}{ France (weighted) } \\
\hline & absolute & relative & absolute & relative & absolute & relative \\
\hline \multicolumn{7}{|l|}{ age at first birth } \\
\hline $14-20$ & 294 & $23 \%$ & 502 & $24 \%$ & 463 & $22 \%$ \\
\hline $21-23$ & 334 & $26 \%$ & 636 & $31 \%$ & 625 & $30 \%$ \\
\hline $24-27$ & 403 & $31 \%$ & 584 & $28 \%$ & 633 & $31 \%$ \\
\hline $28+$ & 262 & $20 \%$ & 341 & $17 \%$ & 342 & $17 \%$ \\
\hline \multicolumn{7}{|c|}{ highest level of respondent's education } \\
\hline missing & 51 & $4 \%$ & - & - & - & - \\
\hline low or no degree & 654 & $51 \%$ & 951 & $46 \%$ & 960 & $46 \%$ \\
\hline medium & 472 & $36 \%$ & 807 & $39 \%$ & 777 & $38 \%$ \\
\hline high & 116 & $9 \%$ & 305 & $15 \%$ & 326 & $16 \%$ \\
\hline \multicolumn{7}{|c|}{ highest level of partner's education } \\
\hline missing & 165 & $13 \%$ & 372 & $18 \%$ & 279 & $14 \%$ \\
\hline low or no degree & 488 & $38 \%$ & 267 & $13 \%$ & 374 & $18 \%$ \\
\hline medium & 249 & $19 \%$ & 663 & $32 \%$ & 861 & $42 \%$ \\
\hline high & 229 & $18 \%$ & 230 & $11 \%$ & 313 & $15 \%$ \\
\hline no partner in household & 162 & $12 \%$ & 531 & $26 \%$ & 236 & $11 \%$ \\
\hline \multicolumn{7}{|l|}{ ever worked: yes or no } \\
\hline missing & 4 & $0 \%$ & - & - & - & - \\
\hline no & 131 & $10 \%$ & 151 & $7 \%$ & 157 & $8 \%$ \\
\hline yes & 1,158 & $90 \%$ & 1,912 & $93 \%$ & 1,906 & $92 \%$ \\
\hline \multicolumn{7}{|c|}{ residence at time of interview } \\
\hline rural $(<2.000)$ & 77 & $6 \%$ & 508 & $25 \%$ & 510 & $25 \%$ \\
\hline rural (2.000-9.999) & 466 & $36 \%$ & 251 & $12 \%$ & 250 & $12 \%$ \\
\hline urban $(>9.999)$ & 750 & $58 \%$ & 1,304 & $63 \%$ & 1,303 & $63 \%$ \\
\hline \multicolumn{7}{|l|}{ residence until age 15} \\
\hline missing & 19 & $1 \%$ & - & - & - & - \\
\hline rural $(<2.000)$ & 188 & $15 \%$ & - & - & - & - \\
\hline rural (2.000-9.999) & 330 & $26 \%$ & - & - & - & - \\
\hline urban $(>9.999)$ & 756 & $58 \%$ & - & - & - & - \\
\hline
\end{tabular}


In Table 5, the distribution of the time-varying covariates for West Germany and France are displayed. Here again, we find arguments that support the assumption of using weights in the analysis of the French FFS. In the unweighted sample size, around $28 \%$ of French female respondents are single during the period at which they are at risk of second birth. The weighted sample documents for this group a proportion of only $16 \%$. So-called "patchwork families" are also overrepresented, because the number of divorced or widowed women is decreasing after using weights. Not using the weights would therefore largely bias the results by overestimating the number of single and divorced women in the data set.

Table 5: Distribution of time at risk according to the various time-varying covariates. Absolute and relative number of person-months, West Germany and France

\begin{tabular}{|l|l|l|l|l|l|l|}
\hline & \multicolumn{2}{|c|}{ West Germany } & \multicolumn{2}{c|}{ France } & \multicolumn{2}{c|}{ France (weighted) } \\
\hline Variables & absolute & relative & absolute & relative & absolute & relative \\
\hline marital status & & & & & & \\
\hline never married & 8,699 & $11 \%$ & 35,089 & $28 \%$ & 18,412 & $16 \%$ \\
\hline married in first order & 53,752 & $70 \%$ & 67,692 & $55 \%$ & 87,725 & $74 \%$ \\
\hline married in higher order & 1,022 & $1 \%$ & 1,499 & $1 \%$ & 1,676 & $1 \%$ \\
\hline divorced/widowed & 6,601 & $9 \%$ & 19,252 & $16 \%$ & 9,538 & $8 \%$ \\
\hline missing & 6,660 & $9 \%$ & 418 & $0 \%$ & 627 & $1 \%$ \\
\hline calendar time (West Germany) & & & & & & \\
\hline until 1974 & 2,619 & $4 \%$ & - & - & - & - \\
\hline $1975-79$ & 9,438 & $12 \%$ & - & - & - & - \\
\hline $1980-82$ & 9,846 & $13 \%$ & - & - & - & - \\
\hline $1983-86$ & 18,450 & $24 \%$ & - & - & - & - \\
\hline $1987-89$ & 18,582 & $24 \%$ & - & - & - & - \\
\hline $1990-92$ & 17,799 & $2 \%$ & - & - & - & - \\
\hline calendar time (France) & & & & & & \\
\hline until 1973 & - & - & 8,659 & $7 \%$ & 11,410 & $9 \%$ \\
\hline $1974-80$ & - & - & 28,877 & $23 \%$ & 31,548 & $27 \%$ \\
\hline $1981-83$ & - & - & 15,669 & $13 \%$ & 15,112 & $13 \%$ \\
\hline $1984-86$ & - & - & 17,470 & $14 \%$ & 15,727 & $13 \%$ \\
\hline $1987-90$ & - & - & 27,125 & $22 \%$ & 23,193 & $20 \%$ \\
\hline $1991-94$ & - & - & 26,150 & $21 \%$ & 20,988 & $18 \%$ \\
\hline Total & 76,734 & $100 \%$ & 123,950 & $100 \%$ & 117,978 & $100 \%$ \\
\hline
\end{tabular}

Another time-varying covariate is the employment status after first childbirth - a variable that is available only for West Germany. Since we constructed this variable with regards to second conception instead of second birth, small differences in the number of exposures appear and we therefore display the distribution of the covariate in a different table (Table 6). Most of the West German women surveyed (49\%) were in employment after first childbirth during the time they were at risk of having a second. 
Table 6: Distribution of time at risk according to the time-varying covariate employment status. Absolute and relative number of person months, West Germany only

\begin{tabular}{|l|l|l|}
\hline & \multicolumn{2}{|c|}{ West Germany } \\
\hline Variables & absolute & relative \\
\hline employment status & & \\
\hline missing & 2,429 & $3 \%$ \\
\hline out of employment after first birth & 30,294 & $40 \%$ \\
\hline in employment after first birth & 37,433 & $49 \%$ \\
\hline never employed & 6,397 & $8 \%$ \\
\hline Total & 76,553 & $100 \%$ \\
\hline
\end{tabular}

Before looking at the results of our multivariate analysis, we will present a short descriptive analysis of the fertility behavior of West German and French women in the FFS. This will give us an insight into the fertility situation in both countries.

\subsection{Descriptive Analysis}

First, we display the absolute number of children in both countries (Figure 6). Looking at the distribution of the family size of women between 35 and 39 years, we find that the degree of childlessness is much higher in West Germany than in France. More than $18 \%$ of all West German women in the sample stayed childless, but only $11 \%$ in France did so. Large differences also exist between the two countries when looking at mothers with at least three children. Only $16 \%$ of the West German women have three or more children whereas the proportion of the French mothers who have three and more children is twice as high.

Figure 6: Distribution of family size in West Germany (cohort 1953-57) and France (cohort 1955-59)

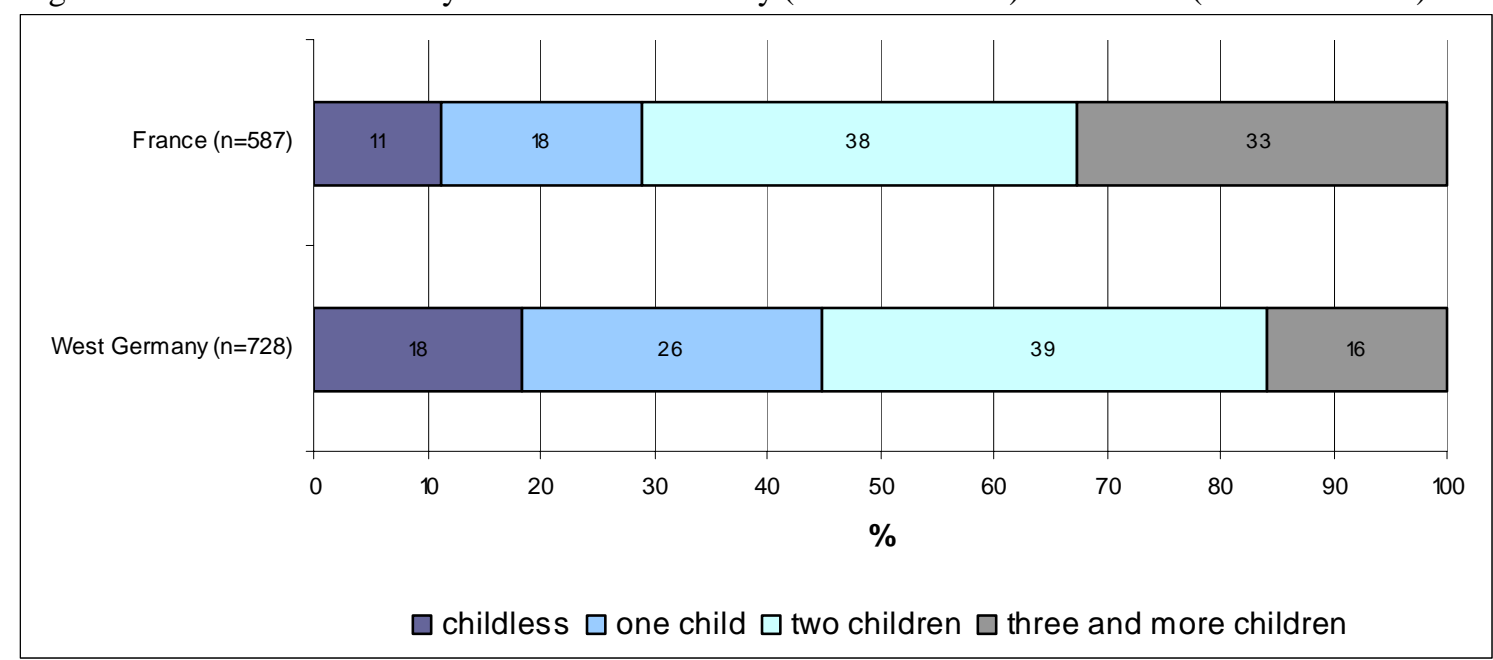

Source: West German FFS 1992, French FFS 1994 
Figure 7 shows the distribution of women with a higher education level (older cohorts) by their number of children. Here, we find support for the polarization hypothesis: In West Germany, we find a polarization between childless women and those with two children. More than $25 \%$ stay childless but also almost $35 \%$ have a second child. For France, this kind of polarization cannot be observed. French women with a high education level have a second child more often than West German women with a university degree (42 vs. $34 \%$ ). But even though highly educated women stay childless to a greater extent than all French women do (18\% vs. 10\%), we cannot find such a polarization tendency as we see in West Germany.

Figure 7: Women with higher education by number of children (in \%). West Germany (cohort 195357), France (cohort 1955-59)

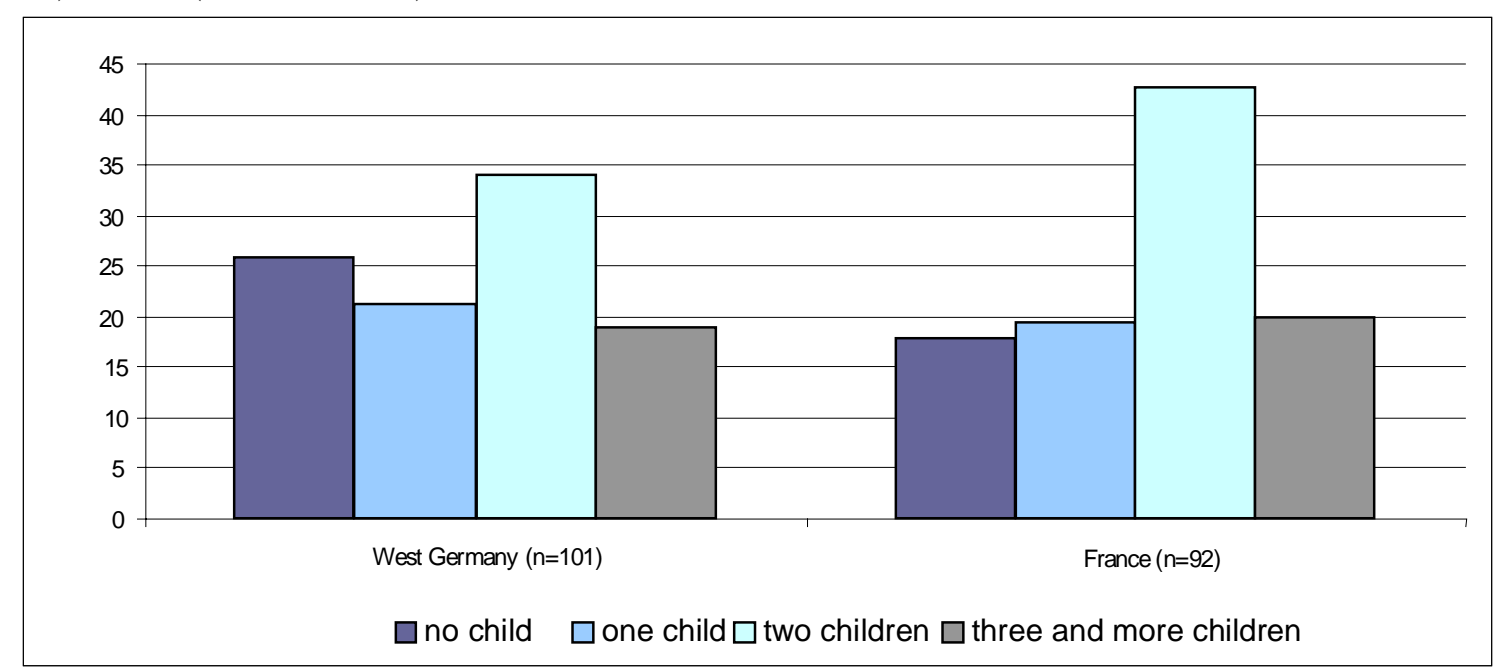

Source: West German FFS 1992, French FFS 1994

Next, the survival curves for the transition to the second child are displayed. Highly educated women in West Germany have higher second birth risks than women with a low or medium education level (Figure 8). Ten years after the first child is born, more than $80 \%$ of the West German highly educated women have a second child while only around $70 \%$ of the women with medium and lower education experienced a second birth.

The same can be observed for highly educated women in France (Figure 9). Here, almost 90\% have a second child ten years after the first child was born. This compares to $77 \%$ of women with medium education. Interestingly, French women with a relatively low level of education, i.e. with no degree or secondary school completion, have a second child more often than women with medium education. 
Figure 8: Transition to second birth by highest level of education of respondent (Kaplan-Meiersurvival-curve). West Germany (cohort 1952-72)

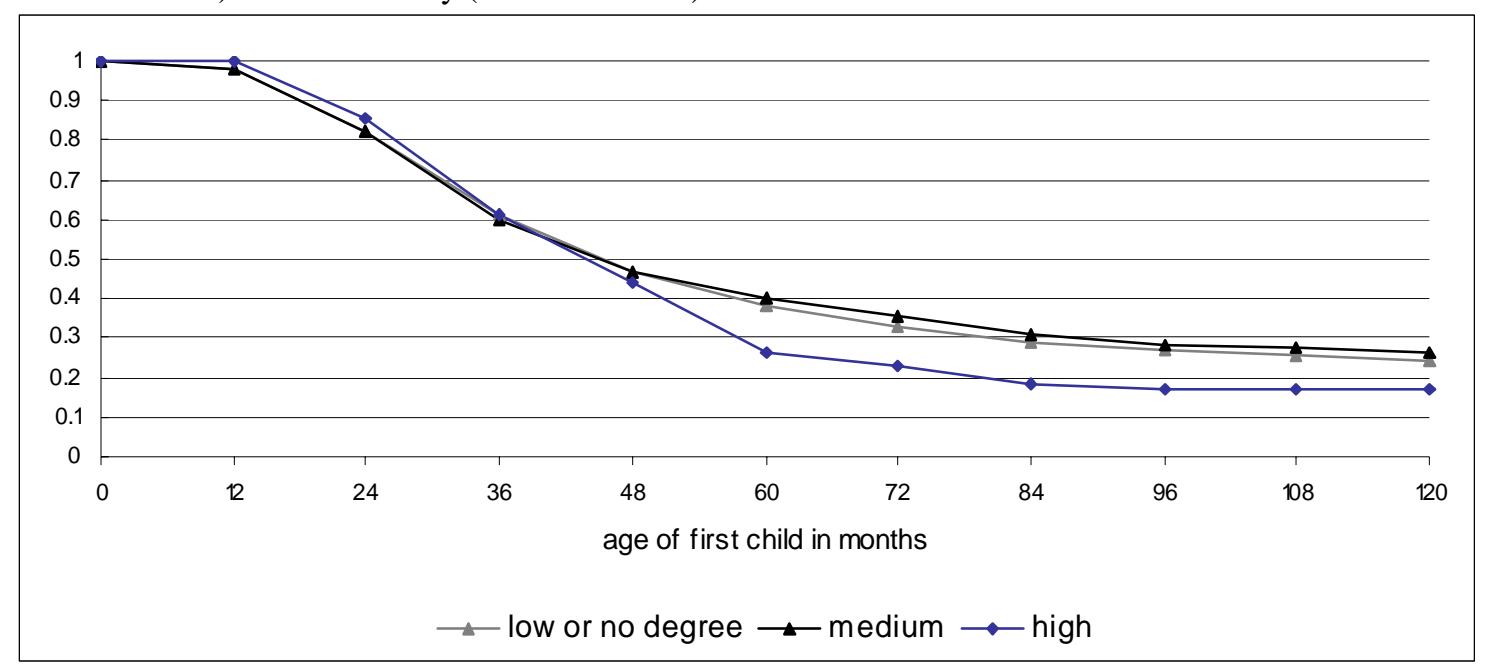

Source: West German FFS 1992

Figure 9: Transition to second birth by highest level of education of respondent (Kaplan-Meiersurvival-curve). France (cohort 1944-73)

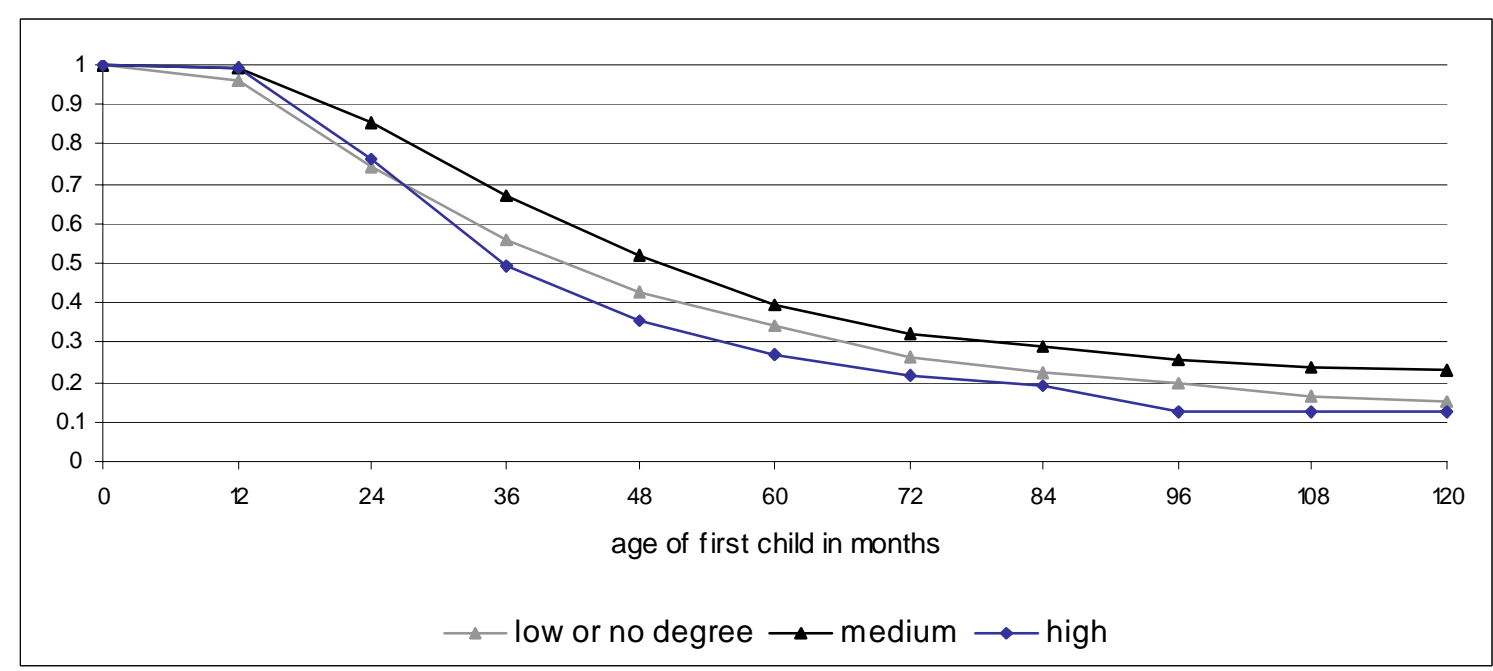

Source: French FFS 1994 (weights used)

Starting from these figures which provided us with some more information on fertility behavior in West Germany and France and point into the same direction as our hypotheses do, we now want to analyse the transition to second birth in close detail. What are the factors that influence the transition to a second child in both countries? Will the effect of education be positive, significant and stable? 


\section{Results}

First, we display the baseline hazard - the absolute second birth risk measured in months since the birth of the first child in both countries (Figure 10). We find that it is higher in France in almost every time interval. Also, the pattern of transition is different: West German women have the highest risk of having a second child when the first child is between 2 and 3 years old. In France, the risk is highest when the first child is between 3 and 4 years of age. There, second births occur even when the first child is older than 10 years. In the West German sample, by contrast, no mother had a second child at this late point in time.

Figure 10: Absolute risk per 1000 person-months:

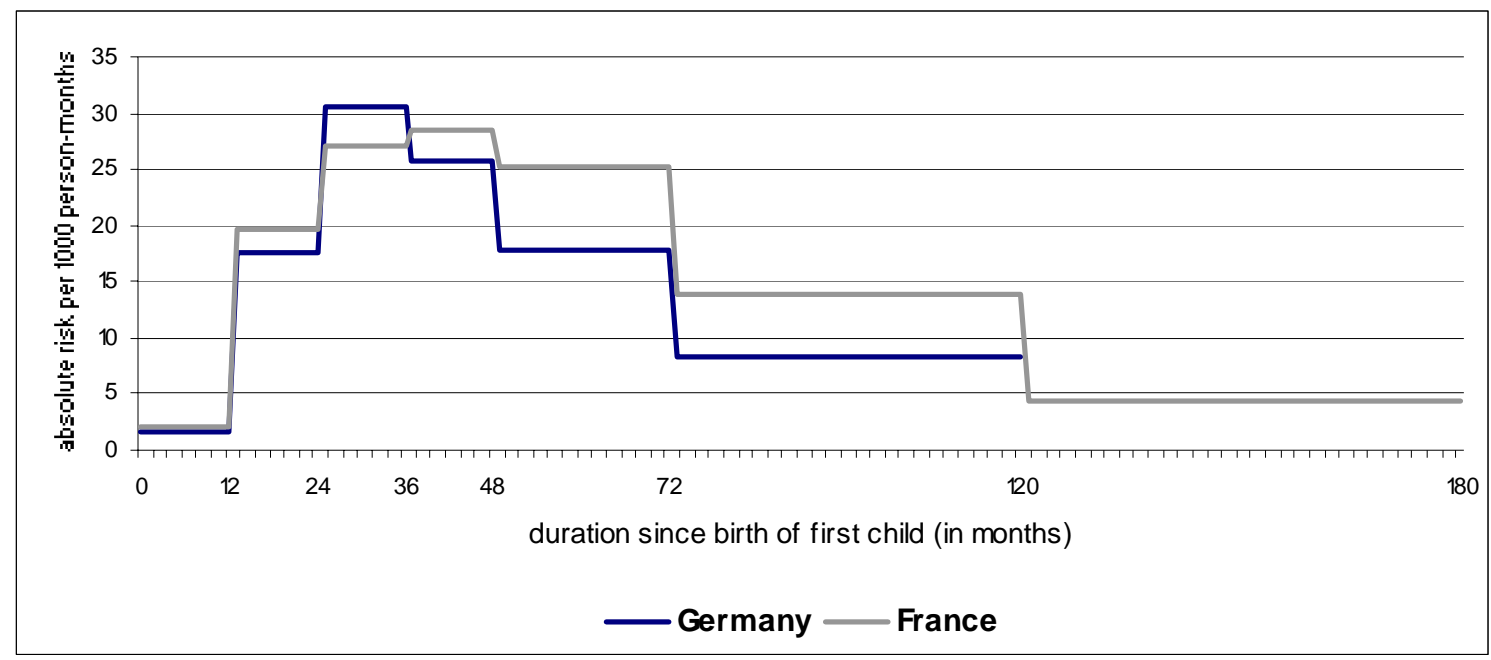

Source: West German FFS 1992, French FFS 1994

The results of our multivariate analysis are displayed in Tables 7 and 8 .

Before interpreting the results, we would like to make a few remarks on the problems related to weights in multivariate analysis. We need to use weights in our analysis because of the oversampling of lone mothers and blended families in the French data set. The weighted number of cases $(1,928)$ has been different than the unweighted equivalents $(2,063)$. Tests of significance are no longer valid because the standard errors are biased. We therefore adjusted the weighting factor by dividing the weight variable by the mean of the weight variable. The relative values of the weights do not change, but they are adjusted so that the mean weight in the sample is 1 , and the sum of weights equals the number of cases. The p-values now can be used. This is because they are no longer biased (for further explanations see Glynn 2004). 
Table 7: Second birth risk for West German women. Cohort 1952-72

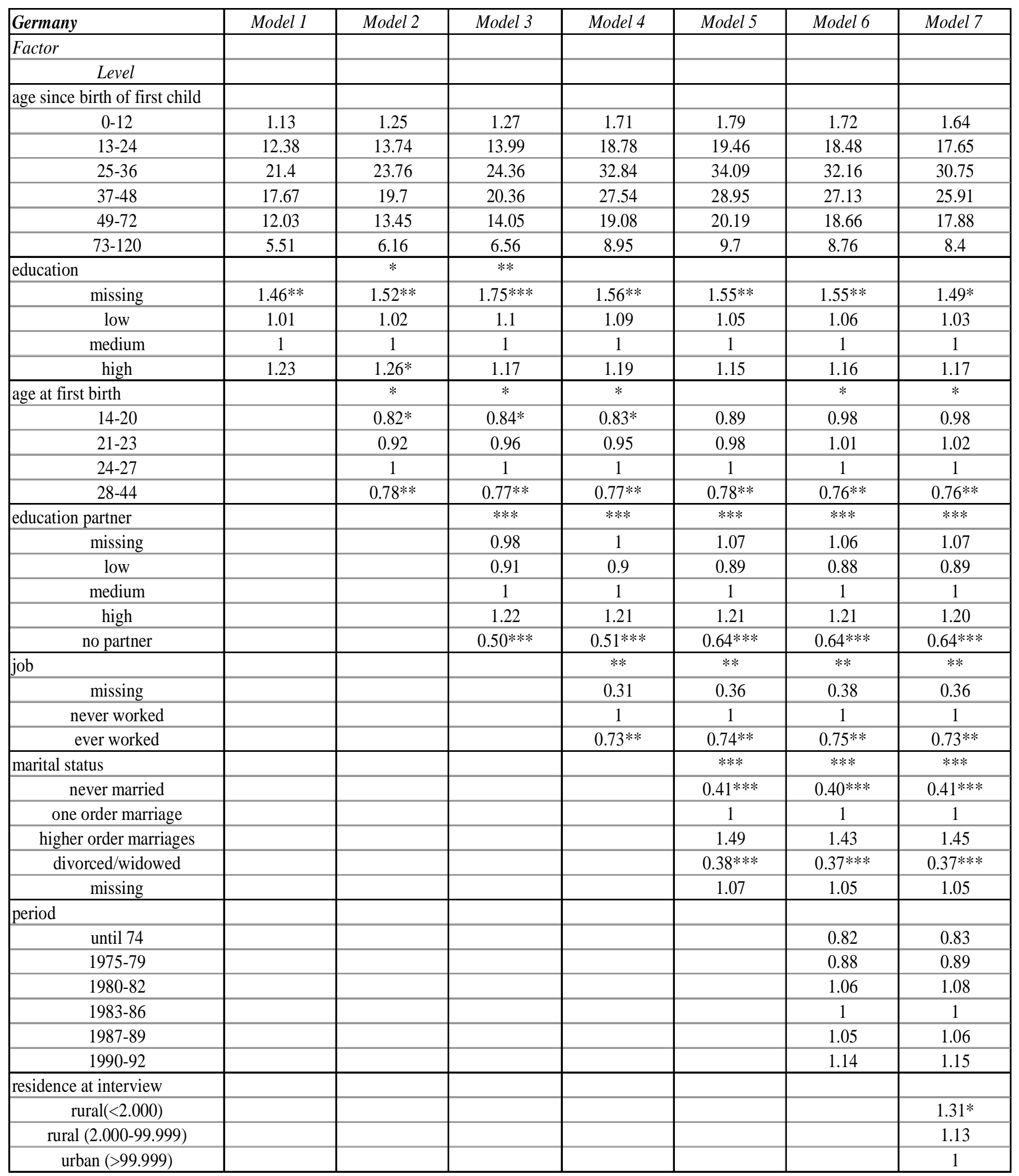

Note: $* * * \mathrm{p} \leq 0.01 ; * * 0.01 \leq \mathrm{p} \leq 0.05 ; * 0.05 \leq \mathrm{p} \leq 0.10$; age since birth of first child=absolute risk per 1000 person-months 
Table 8: Second birth risk for French women. Cohort 1944-73

\begin{tabular}{|c|c|c|c|c|c|c|c|}
\hline France & Model 1 & Model 2 & Model 3 & Model 4 & Model 5 & Model 6 & Model 7 \\
\hline \multicolumn{8}{|l|}{ Factor } \\
\hline \multicolumn{8}{|l|}{ Level } \\
\hline \multicolumn{8}{|l|}{ age since birth of first child } \\
\hline $0-12$ & 1.48 & 1.36 & 1.38 & 2.06 & 2.16 & 2.03 & 1.94 \\
\hline $13-24$ & 14.60 & 13.49 & 13.66 & 20.51 & 21.19 & 20.25 & 19.31 \\
\hline $25-36$ & 19.59 & 18.11 & 18.43 & 27.82 & 29.03 & 27.96 & 26.65 \\
\hline $37-48$ & 19.57 & 18.02 & 18.49 & 28.04 & 30.17 & 29.31 & 28 \\
\hline $49-72$ & 16.74 & 15.35 & 15.91 & 24.19 & 26.66 & 26.14 & 25.05 \\
\hline $73-120$ & 8.43 & 7.75 & 8.1 & 12.45 & 14.32 & 14.34 & 13.82 \\
\hline $121-180$ & 2.92 & 2.66 & 2.78 & 4.29 & 4.59 & 4.64 & 4.52 \\
\hline \multicolumn{8}{|l|}{ education } \\
\hline low & $1.29 * * *$ & $1.22 * * *$ & $1.28 * * *$ & $1.24 * * *$ & $1.23 * * *$ & $1.22 * * *$ & $1.22 * * *$ \\
\hline medium & 1 & 1 & 1 & 1 & 1 & 1 & 1 \\
\hline high & $1.49 * * *$ & $1.65^{* * *}$ & $1.56^{* * * *}$ & $1.57^{* * *}$ & $1.53 * * *$ & $1.52 * * *$ & $1.52 * * *$ \\
\hline \multicolumn{8}{|l|}{ age at first birth } \\
\hline $14-20$ & & $1.32 * * *$ & $1.36 * * *$ & $1.34 * * *$ & $1.40 * * *$ & $1.32 * * *$ & $1.31 * * *$ \\
\hline $21-23$ & & $1.15^{* *}$ & $1.17 * *$ & $1.15^{* *}$ & 1.12 & 1.08 & 1.08 \\
\hline $24-27$ & & 1 & 1 & 1 & 1 & 1 & 1 \\
\hline $28-44$ & & $0.86^{*}$ & $0.84 *$ & $0.84 * *$ & $0.84 *$ & $0.85^{*}$ & $0.85^{*}$ \\
\hline \multicolumn{8}{|l|}{ education partner } \\
\hline missing & & & 0.92 & 0.9 & 1.02 & 0.99 & 1.02 \\
\hline low & & & 0.9 & 0.92 & 0.9 & $0.88^{*}$ & $0.88^{*}$ \\
\hline medium & & & 1 & 1 & 1 & 1 & 1 \\
\hline high & & & $1.21 * *$ & $1.22 * *$ & $1.25^{* *}$ & $1.23 * *$ & $1.26^{* * *}$ \\
\hline no partner & & & $0.70 * * *$ & $0.7 * * *$ & 0.92 & 0.91 & 0.92 \\
\hline \multicolumn{8}{|l|}{ job } \\
\hline never worked & & & & 1 & 1 & 1 & 1 \\
\hline ever worked & & & & $0.66 * * *$ & $0.66 * * *$ & $0.65 * * *$ & $0.66 * * *$ \\
\hline \multicolumn{8}{|l|}{ marital status } \\
\hline never married & & & & & $0.54 * * *$ & $0.55 * * *$ & $0.56^{* * *}$ \\
\hline one order marriage & & & & & 1 & 1 & 1 \\
\hline higher order marriages & & & & & $2.31 * * *$ & $2.31 * * *$ & $2.37 * * *$ \\
\hline divorced/widowed & & & & & $0.32 * * *$ & $0.32 * * *$ & $0.32 * * *$ \\
\hline missing & & & & & 0.67 & 0.69 & 0.70 \\
\hline \multicolumn{8}{|l|}{ period } \\
\hline until 1973 & & & & & & $1.34 * *$ & $1.33^{* *}$ \\
\hline $1973-80$ & & & & & & 1.08 & 1.09 \\
\hline $1981-83$ & & & & & & 1.04 & 1.04 \\
\hline $1984-86$ & & & & & & 1 & 1 \\
\hline $1987-90$ & & & & & & 1.03 & 1.02 \\
\hline 1991-94 & & & & & & 1.07 & 1.07 \\
\hline \multicolumn{8}{|l|}{ residence at interview } \\
\hline rural $(<2.000)$ & & & & & & & $1.14 * *$ \\
\hline rural (2.000-99.999) & & & & & & & 0.97 \\
\hline urban $(>99.999)$ & & & & & & & 1 \\
\hline
\end{tabular}

Note: $* * * \mathrm{p} \leq 0.01 ; * * 0.01 \leq \mathrm{p} \leq 0.05 ; * 0.05 \leq \mathrm{p} \leq 0.10$; age since birth of first child=absolute risk per 1000 person-months 
We estimated multiplicative models by means of step-wise event-history modeling. First, the effect of the highest education level of the women was analyzed (Model 1). West German women with higher education have a second birth risk that is $23 \%$ higher than that for women with medium education (reference category). French women with a university degree even have a risk that is $49 \%$ higher. Compared to West Germany, lowly educated French women show a relatively high risk of having a second child: It is $29 \%$ higher than for the reference group. Next, we add age at first birth to our model to see whether the positive effect of education is mainly produced by late age at first birth. We find that the effect of education increases in both countries (Model 2). The earlier a women in France starts with childbearing, the higher is her second birth risk. For Germany, we cannot find such a significant effect. In both countries, late age at first birth (28+) lowers the risk of having a second child by around $20 \%$ compared to age group 24-27. If the higher risk of highly educated women is connected to late age at first birth, the positive effect should have disappeared or at least weakened after controlling for age at first birth. This is not the case, however. The positive effect of education can therefore not be attributed to late age at first birth. To examine the connection between education and age at first birth in greater detail, we employed an interaction between both variables (Tables 9a and 9b).

Table 9a: Transition to second birth for West German women: Interaction between highest level of education of respondent and age at first birth (controlled for education of partner, employment status, marital status, calendar time and place of residence at interview)

\begin{tabular}{|l|l|l|l|}
\hline & \multicolumn{3}{|c|}{ highest level of education of the respondent } \\
\hline age at first birth & no or low degree & medium degree & high degree \\
\hline $14-20$ & 1.08 & 0.87 & 0.58 \\
\hline $21-23$ & 1.1 & $\mathbf{1}$ & 0.81 \\
\hline $24-27$ & 0.94 & 1.15 & 1.31 \\
\hline $28-44$ & 0.81 & 0.7 & 1.1 \\
\hline
\end{tabular}

Source: West German FFS 1992

Table 9b: Transition to second birth for French women: Interaction between highest level of education of respondent and age at first birth (controlled for education of partner, employment status, marital status, calendar time and place of residence at interview)

\begin{tabular}{|l|l|l|l|}
\hline & \multicolumn{3}{|c|}{ highest level of education of the respondent } \\
\hline age at first birth & no or low degree & medium degree & high degree \\
\hline $14-20$ & 1.59 & 1.17 & 1.37 \\
\hline $21-23$ & 1.31 & $\mathbf{1}$ & 1.58 \\
\hline $24-27$ & 1.11 & 0.96 & 1.58 \\
\hline $28-44$ & 0.84 & 0.99 & 1.13 \\
\hline
\end{tabular}

Source: French FFS 1994 
Compared to the reference group (medium educated women, age 21-23), West German women with higher education have a $31 \%$ higher risk of having a second child when they had their first child aged between 24 and 27. French women who had their first birth between 24 and 27 years of age have a second birth risk that is even double as high. This supports our assumption that highly educated women have their first child later in life and therefore have a higher second birth risk at older ages than lowly educated women. The very high risk of lowly educated women in France who start childbearing at very low ages (14-20) is remarkable. They encounter a more than $50 \%$ higher risk than medium educated women do. However, the higher second birth intensity for highly educated French women who gave birth to their first child between 14 and 20 years of age can in principle be disregarded because only 8 out of 305 women with a university degree fall into this group. In West Germany, we find 8 out of 116 women in this group. Most of the women with higher education have their first child later than age 28 (West Germany) or aged between 24 and 27 years (France). A low age at childbearing is a particular characteristic of women with no or lower degrees: $35 \%$ of French women with a relatively low education have their first child between age 14 and 20, while $31 \%$ of West German women in the same category do so.

Third, we control for the education degree of the woman's partner.

One clearly notes a decrease in second birth intensities of highly educated West German women (Table 7, Model 3). Before controlling for the partner's characteristics, these women had a $26 \%$ higher risk of having a second child. Now it is only $17 \%$ higher than in the reference category and it is no longer significant. In other words, the influence of the education level on the transition rates to the second child weakened. After adding the education degree of the women's partner to the model, we can observe the following: A university degree of the partner has a strong influence on second birth risk. West German women with highly educated partners have a $22 \%$ higher second birth risk than women with a partner of medium education. In France, the risk for women with highly educated partners is also high. But in contrast to West Germany, the positive effect of women's education remains significantly high and stable after controlling for the partner's education (Table 8 , Model 3).

When we employ an interaction between the education of the woman and her partner's education level (Tables 10a and 10b), we see that the higher education of 
West German women is not positively connected to second birth risks. This holds for the education of the partner only. When both of them are highly educated, they have the highest risk of all groups. In France, higher female education increases the risk of second birth, irrespective of the partner's degree. French women with higher education have a $28 \%$ higher risk if the partner has no or a low degree and the risk is higher by $74 \%$ when the partner has a medium education.

Table 10a: Transition to the second child for West German women: Interaction between woman's highest level of education and partner's highest level of education (controlled for age at first birth, employment status, marital status, calendar time, residence at interview)

\begin{tabular}{|l|l|l|l|l|}
\hline & \multicolumn{4}{|c|}{ highest level of partner's education } \\
\hline $\begin{array}{l}\text { highest level of woman's } \\
\text { education }\end{array}$ & $\begin{array}{l}\text { no or low } \\
\text { degree }\end{array}$ & medium & high & no partner \\
\hline no or low degree & 1.01 & 1.33 & 1.06 & 0.76 \\
\hline medium & 0.89 & $\mathbf{1}$ & 1.47 & 0.89 \\
\hline high & 1.02 & 0.96 & 1.58 & 1.27 \\
\hline
\end{tabular}

Source: West German FFS 1992

Table 10b: Transition to the second child for French women: Interaction between woman's highest level of education and partner's highest level of education (controlled for age at first birth, employment status, marital status, calendar time, residence at interview)

\begin{tabular}{|l|l|l|l|l|}
\hline & \multicolumn{4}{|c|}{ highest level of partner's education } \\
\hline $\begin{array}{l}\text { highest level of woman's } \\
\text { education }\end{array}$ & $\begin{array}{l}\text { no or low } \\
\text { degree }\end{array}$ & medium & high & no partner \\
\hline no or low degree & 1.01 & 1.12 & 1.47 & 1.18 \\
\hline medium & 0.92 & $\mathbf{1}$ & 1.16 & 0.81 \\
\hline high & 1.28 & 1.74 & 1.92 & 1.19 \\
\hline
\end{tabular}

Source: French FFS 1994

In West Germany, by contrast, the education level of the partner especially seems to determine higher transition rates to second births. This confirms our assumption on the impact of men's education on fertility in West Germany. The gender specific division of labor confirms the model of the "male bread-winner" and the female housewife. It is not her education - and connected with that, her employment and income - that mainly determines the number of children but the husband's education and economic situation. There is an independent effect of the education level of French women. They seem to convert their level of education into gainful employment and a higher income more easily than their West German neighbors do. They are able to support a larger family, especially when their husbands or partners have a higher education as well: The probability that both have a higher income and are able to afford more children is high. 
To analyze the effect of the employment status, a variable was added that measures whether the woman was ever or never employed. As expected, women who have never been employed in their life have a higher second birth risk in both countries than mothers who have worked before (Model 4). In both countries, the group of women that were never employed consists mainly of the lowly educated. Around 9\% of West German women with a relatively low education and $10 \%$ of their French counterparts have never been in gainful employment. Women with a university degree never worked to a very low number in both countries (3\% in West Germany and $1 \%$ in France).

Next, we control for marital status. In both countries, married women have a much higher risk than unmarried ones do (Model 5). This result confirms our assumptions. Especially in France, this group may be very selective. Those who decide to marry are the ones who are very family-oriented and therefore have higher transition rates than women who have never married (single or cohabiting). As expected, women in higher-order marriages have also higher second birth risks. Divorced women experience lower risks.

The variables period and place of residence at interview are not significant in both countries (Models 6 and 7). In West Germany, there is an increase in second birth intensities over time - they are lowest before 1974 and highest between 1990 and 1992 (reference category is the period 1983-1986). In France, the risks do not change at all, except before 1973, where the second birth risk was at a higher level than in the mid-eighties. It is hard to tell whether this may be due to family policy changes or general economic or social factors.

As hypothesized before - living in a rural environment increases the second birth risk by more than $30 \%$ in West Germany and around $14 \%$ in France.

Finally, we estimated a separate model for West Germany where we included two additional variables to find out whether the results change or not (Table 11). We get similar results when including a time-varying variable representing the employment status after first childbirth and a time-fixed variable that measures the influence of the place of residence until age 15. Being in employment after first birth reduces the risk of having a second child by around $40 \%$. Women who have never been employed neither before nor after first birth - have a slightly higher second birth risk (Table 11, Model 4). This result suggests that work and family life are rather incompatible, as we expected. 
Table 11: Second conception risk for West German women (two additional variables)

\begin{tabular}{|c|c|c|c|c|c|c|c|}
\hline Germany & Model 1 & Model 2 & Model 3 & Model 4 & Model 5 & Model 6 & Model 7 \\
\hline \multicolumn{8}{|l|}{ Factor } \\
\hline \multicolumn{8}{|l|}{ Level } \\
\hline \multicolumn{8}{|l|}{ age since birth of first child } \\
\hline $0-12$ & 1.14 & 1.26 & 1.28 & 1.48 & 1.53 & 1.49 & 1.41 \\
\hline $13-24$ & 12.43 & 13.78 & 14.01 & 16.14 & 16.5 & 15.96 & 15.11 \\
\hline $25-36$ & 21.49 & 23.83 & 24.39 & 28.4 & 29.06 & 27.98 & 26.53 \\
\hline $37-48$ & 17.76 & 19.77 & 20.39 & 24 & 24.86 & 23.82 & 22.64 \\
\hline $49-72$ & 12.09 & 13.5 & 14.08 & 16.75 & 17.43 & 16.5 & 15.72 \\
\hline $73-120$ & 5.55 & 6.19 & 6.58 & 7.95 & 8.45 & 7.86 & 7.48 \\
\hline education & & $*$ & $* *$ & & & & \\
\hline missing & $1.46^{*}$ & $1.51^{* *}$ & $1.73^{* * *}$ & $1.48^{*}$ & $1.47^{*}$ & $1.47^{*}$ & $1.44^{*}$ \\
\hline low & 1 & 1.01 & 1.09 & 1.05 & 1.01 & 1.02 & 1 \\
\hline medium & 1 & 1 & 1 & 1 & 1 & 1 & 1 \\
\hline high & 1.22 & 1.25 & 1.17 & 1.22 & 1.18 & 1.19 & 1.19 \\
\hline age at first birth & & & $*$ & $*$ & $*$ & $* *$ & $*$ \\
\hline $14-20$ & & $0.83^{*}$ & 0.85 & 0.9 & 0.96 & 1.04 & 1.04 \\
\hline $21-23$ & & 0.92 & 0.96 & 0.99 & 1.01 & 1.04 & 1.05 \\
\hline $24-27$ & & 1 & 1 & 1 & 1 & 1 & 1 \\
\hline $28-44$ & & $0.78^{* *}$ & $0.77 * *$ & $0.76^{* *}$ & $0.76^{* *}$ & $0.75^{* *}$ & $0.76^{* *}$ \\
\hline education partner & & & **** & **** & $* * *$ & **** & **** \\
\hline missing & & & 0.98 & 1.07 & 1.14 & 1.13 & 1.14 \\
\hline low & & & 0.91 & 0.93 & 0.92 & 0.91 & 0.91 \\
\hline medium & & & 1 & 1 & 1 & 1 & 1 \\
\hline high & & & 1.22 & $1.27^{* *}$ & $1.26^{*}$ & $1.26^{*}$ & $1.26^{*}$ \\
\hline no partner & & & $0.5 * * *$ & $0.55^{* * * *}$ & $0.67 * *$ & $0.67 * *$ & $0.68^{* *}$ \\
\hline employment status after first birth & & & & **** & $* * *$ & $* * *$ & $* * *$ \\
\hline missing & & & & $0.57^{* *}$ & $0.6^{*}$ & $0.61^{*}$ & $0.58^{*}$ \\
\hline out of employment after first birth & & & & 1 & 1 & 1 & 1 \\
\hline in employment after first birth & & & & $0.63^{* * *}$ & $0.67 * * *$ & $0.67^{* * *}$ & $0.66 * * *$ \\
\hline never employed & & & & 1.09 & 1.11 & 1.1 & 1.1 \\
\hline marital status & & & & & $* * *$ & $* * *$ & $* * *$ \\
\hline never married & & & & & $0.43^{* * *}$ & $0.43^{* * *}$ & $0.44 * * *$ \\
\hline one order marriage & & & & & 1 & 1 & 1 \\
\hline higher order marriages & & & & & 1.45 & 1.4 & 1.44 \\
\hline divorced/widowed & & & & & $0.4 * * *$ & $0.39 * * *$ & $0.4 * * *$ \\
\hline missing & & & & & 1.1 & 1.08 & 1.08 \\
\hline \multicolumn{8}{|l|}{ period } \\
\hline until 74 & & & & & & 0.84 & 0.83 \\
\hline $1975-79$ & & & & & & 0.9 & 0.91 \\
\hline $1980-82$ & & & & & & 1.08 & 1.09 \\
\hline $1983-86$ & & & & & & 1 & 1 \\
\hline $1987-89$ & & & & & & 1.04 & 1.04 \\
\hline $1990-92$ & & & & & & 1.11 & 1.11 \\
\hline \multicolumn{8}{|l|}{ residence until age 15} \\
\hline missing & & & & & & & 1.55 \\
\hline $\operatorname{rural}(<2.000)$ & & & & & & & 1.13 \\
\hline rural (2.000-99.999) & & & & & & & 1.12 \\
\hline urban $(>99.999)$ & & & & & & & 1 \\
\hline
\end{tabular}

Note: ${ }^{* *} \mathrm{p} \leq 0.01 ; * * 0.01 \leq \mathrm{p} \leq 0.05 ; * 0.05 \leq \mathrm{p} \leq 0.10$; age since birth of first child=absolute risk per 1000 person-months 
Interestingly, after adding the employment variable, the risk for women with highly educated partners increases and gets significant. This may be due to the fact that women with highly educated partners can abstain from work more easily than women with partners that have a lower degree and earn less money than men with a university degree. When we employ an interaction between the employment status after first birth and the education level of the partner (Table 12), we find women with higher educated partners to have a much higher risk when not being employed after the birth of their first child than women in the reference category.

Table 12: Transition to second birth for West German women: Interaction between highest level of education of the partner and employment status after first birth (controlled for education of respondent, age at first birth, marital status, calendar time and place of residence at age 15)

\begin{tabular}{|l|r|r|r|}
\hline & \multicolumn{3}{|c|}{ employment status after first birth } \\
\hline $\begin{array}{l}\text { highest level of education } \\
\text { of partner }\end{array}$ & out of employment & in employment & never employed \\
\hline no or low degree & 1.51 & 1 & 1.69 \\
\hline medium & 1.66 & $\mathbf{1}$ & 2.07 \\
\hline high & 2.27 & 1.3 & 1.72 \\
\hline no partner & 1.02 & 0.81 & 1.84 \\
\hline
\end{tabular}

Source: West German FFS 1992

The risk for women with highly educated partners is more than $100 \%$ higher than for those with medium or lowly educated partners - these women look after the household and the children while the partner is making an income. This finding, too, can be interpreted as supporting the male breadwinner model in West Germany. It supports one-earner families, especially when the husband has a higher education and earns a higher income.

\section{Conclusion}

This paper aimed at comparing the second birth risks of French and West German women by concentrating on the effect of the education level. To measure the effect of education on the transition to the second child, we estimated a stepwise multiplicative intensity-regression model. A comparison of the institutional constraints in the two countries showed a stronger incompatibility between work and family life in West Germany than in France because of institutional constraints that hamper mothers' employment. Especially women with a university degree suffer from decision conflicts. If they want to convert their accumulated human capital into gainful 
employment and income, they often need to forego childbearing. The opportunity costs concomitant to raising children and giving up employment are especially high for this group. Descriptive statistics showed a "polarization" between higher educated women in West Germany who stay childless and those who have more than one child. We therefore expected higher second birth risks for West German women with high education who were already mother of one child. They decided in favor of a family and against a career. Also for French women with a university degree, a higher second birth risk was assumed but for different reasons. French women with a high education should be able to support a larger family by investing their higher income into family size. Work and family life are compatible in France - inexpensive and widely accepted public childcare helps mothers to combine employment and childrearing.

The multivariate model supports our assumptions but it also provides new insights into the underlying patterns. To have a higher education increases the risk of having a second child by more than $20 \%$ in both countries without controlling for other factors. After controlling for age at first birth, the higher risks of highly educated women increase slightly. When we control for the education level of the partner, countryspecific differences can be seen: The influence of the elevated risk for highly educated West German women decreases and reaches insignificance. There is no independent effect of female education but it is mainly the education degree of the partner that determines second birth risks. We do not observe a similar pattern for France. French women with a university degree have - independent of the education level of their partners - a second birth risk that is more than $50 \%$ higher than it is for medium educated women. Even after controlling for other variables, such as marital status, employment status or place of residence, the pattern does not change. Never being employed increases the second birth risk for women in both countries. West German women who have a partner with a higher degree and are not employed or stopped working after the birth of their first child have a much higher second birth risk than the reference group (the partner has a medium degree and the woman is employed after the first birth). The strong effect of the partner's education in West Germany suggests that the male breadwinner regime in West Germany still exists, in spite of increasing female employment rates and the changing role of women in society. Low child care provisions for children below age 3 and inadequate opening hours of Kindergärten for children between aged 3 to 6 make it hard for West German parents to be employed. Connected with tax disadvantages for full-time working 
women, the institutional framework supports and prolongs the interruption of maternal gainful employment. To decrease the costs of income loss, the parent with a lower income will stay at home and care for the children. This is mostly the woman. It is therefore difficult for West German mothers to reconcile their stay in the labor market with their desire for children. At the same time, the role of the partner/husband assumes greater importance: His education level and income determine the family size. The economic position of the male breadwinner seems to have a strong influence on the number of children.

Contrary to West Germany, well-educated French women are able to support a relatively large family without depending on their partner's education degree. They can rely on several state-aided measures that support female labor-force participation and family life. Inexpensive all-day-care for children aged 3 to 6 and all-day-schools for older children facilitate maternal employment.

One should bear in mind that these measures are not only aimed at combining work and family life but also at increasing family size (most of the measures apply to mothers with at least two children). Also note that it is not possible with our data to measure the degree of female individual autonomy in West Germany and France. In both countries, women are still responsible for the majority of domestic work ${ }^{3}$. But all in all, there is an indication that it is easier for French women to combine work and family life than it is for their West German contemporaries.

\section{Acknowledgement}

I would like to thank Michaela Kreyenfeld for her valuable comments on ealier versions of this paper and Susann Backer for language editing.

I would also like to thank the advisory Group of the FFS program of comparative research for its permission, granted under identification number 75 , to use the FFS data on which this study is based.

\footnotetext{
${ }^{3}$ In France, women in gainful employment spend more than twice as much time per week on domestic work (4 hours and 15 minutes a day) than French men do ( 2 hours and 10 minutes a day) (European Commission 2000).
} 


\section{References}

Anttonen, Anneli / Sipilä, Jorma (1996): European social care services: is it possible to identify models?. In: Journal of European Social Policy, vol. 6, no. 2, pp. 87-100.

Becker, Andrea (2000): Mutterschaft im Wohlfahrtsstaat. Familienbezogene Sozialpolitik und die Erwerbsintegration von Frauen in Deutschland und Frankreich. Berlin: Wissenschaftlicher Verlag Berlin.

Becker, Gary S. (1985): Human Capital, Effort, and the Sexual Division of Labor. In: Journal of Labor Economics, vol. 3, no. 1, pt. 2, pp. 33-58.

Becker, Gary S. (1993): A treatise on the family. Enlarged Edition. Cambridge, Massachusetts: Harvard University Press.

Blossfeld, Hans-Peter / Huinink, Johannes (1989): Die Verbesserung der Bildungsund Berufschancen von Frauen und ihr Einfluß auf den Prozeß der Familienbildung. In: Zeitschrift für Bevölkerungswissenschaft, vol. 45, no. 4, pp. 383-404.

Blossfeld, Hans-Peter / Huinink, Johannes (1991): Human capital investments or norms of role transition? How women's schooling and career affect the process of family formation. In: American Journal of Sociology, vol. 97, no. 1, pp. 143-168.

Council of Europe (Ed.) (2001): Recent demographic developments in Europe: Demographic Yearbook 2001.

Dingeldey, Irene (2000): Begünstigungen und Belastungen familialer Erwerbs- und Arbeitszeitmuster in Steuer- und Sozialversicherungssystemen - Ein Vergleich zehn europäischer Länder. Gelsenkirchen: Institut Arbeit und Technik.

Ermisch, John F. (1988): Purchased child care, optimal family size and mother's employment. Theory and econometric analysis. In: Journal of Population Economics, vol. 2, pp. 79-102.

Esping-Andersen, Gøsta (1990): The three worlds of welfare capitalism. Cambridge: Polity Press.

Esping-Andersen, Gøsta (1999): Social foundations of Postindustrial Economies. Oxford: Oxford University Press.

European Commission (2000):Wie verwenden Frauen und Männer ihre Zeit? Drei europäische Studien. Beschäftigung und soziale Angelegenheiten, Luxemburg: Amt für amtliche Veröffentlichungen der Europäischen Gemeinschaften.

European Commission (Ed.) (2002): Europäische Sozialstatistik - Bevölkerung. Luxemburg: Amt für amtliche Veröffentlichungen der Europäischen Gemeinschaften.

Eurostat (Ed.) (2001): New Cronos. 
Fagnani, Jeanne (2002): Why do French women have more children than German women? Family policies and attitudes towards child care outside home. In: Community, Work \& Family, vol. 5, no. 1, pp. 103-120.

Glynn, Patty (2004): Weighting and Adjusting Weights: An Example. http://staff.washington.edu/glynn/adjweight2.pdf, 26.03.2004, Washington.

Gornick, Janet C. / Meyers, Marcia M. / Ross, Katherin E. (1997): Supporting the employment of mothers: Policy variation across fourteen welfare states. In: Journal of European Social Policy, vol. 7, no. 1, pp. 45-70.

Gornick, Janet C. / Meyers, Marcia M. / Ross, Katherin E. (1998): Public policies and the employment of mothers: a cross-national study. In: Social Science Quarterly, vol. 79 , no. 1 , pp. $35-54$.

Grundmann, Matthias / Huinink, Johannes / Krappmann, Lothar (1994): Familie und Bildung. Empirische Ergebnisse und Überlegungen zur Frage der Beziehung von Bildungsbeteiligung, Familienentwicklung und Sozialisation. In: Peter Büchner u.a.: Kindliche Lebenswelten, Bildung und innerfamiliale Beziehungen. Materialien zum 5. Familienbericht, vol. 4, München: Verlag Deutsches Jugendinstitut, pp. 41-104.

Hank, Karsten / Kreyenfeld, Michaela / Spieß, Katharina C. (2003): Kinderbetreuung und Fertilität in Deutschland. MPIDR Working Paper, WP 2003-002, Rostock: Max Planck Institute for Demographic Research.

Hoem, Britta / Hoem, Jan M (1989): The impact of women's employment on second and third births in modern Sweden. In: Population Studies, vol. 43, pp. 47-67.

Hoem, Britta (1993): The compatibility of employment and childbearing in contemporary Sweden. In: Acta Sociologica, vol. 36, pp. 101-120.

Hoem, Jan M. (1996): The Harmfulness or Harmlessness of Using an Anticipatory Regressor: How Dangerous Is It to Use Education Achieved as of 1990 in the Analysis of Divorce Risks in Earlier Years?. In: Yearbook of Population Research in Finland, vol. 33, pp. 34-43.

Hoem Jan M. / Prskawetz, Alexia / Neyer, Gerda (2001): Autonomy or conservative adjustment? The effect of public policies and educational attainment on third births in Austria, 1975-96. In: Population Studies, vol. 55, pp. 249-261.

Huinink, Johannes (1989): Das zweite Kind. Sind wir auf dem Weg zur Ein-KindFamilie?. In: Zeitschrift für Soziologie, vol. 18, no. 3, pp. 192-207.

Huinink, Johannes (1995): Warum noch Familie? Zur Attraktivität von Partnerschaft und Elternschaft in unserer Gesellschaft. Frankfurt/Main und New York: Campus Verlag. 
Huinink, Johannes (2002): Polarisierung der Familienentwicklung in europäischen Ländern im Vergleich. In: Schneider, Norbert F. / Matthias-Bleck, Heike (Eds.): Elternschaft heute. Gesellschaftliche Rahmenbedingungen und individuelle Gestaltungsaufgaben. Opladen: Leske und Budrich, pp. 49-73.

Klein, T. / Lengerer, A. / Uzelac, M. (2002): Partnerschaftliche Lebensformen im internationalen Vergleich. In: Zeitschrift für Bevölkerungswissenschaften, vol. 27, no. 3, pp. 359-379.

Kravdal, Øystein (1992): The emergence of a positive relationship between education and third birth rates in Norway with supportive evidence from the United States. In: Population Studies, vol. 46, no. 3, pp. 459-475.

Kreyenfeld, Michaela (2002): Parity Specific Birth Rates for West Germany: An Attempt to Combine Survey Data and Vital Statistics. In: Zeitschrift für Bevölkerungswissenschaft, vol. 27, no. 3, pp. 327-357.

Kreyenfeld, Michaela (2002): Time-squeeze, partner effect or self-selection? An investigation into the positive effect of women's education on second birth risks in West Germany. In: Demographic Research, vol. 7, no. 2, pp. 15-48.

Kreyenfeld, Michaela (2004): Fertility decisions in the FRG and GDR: An analysis with data from the German fertility and family survey. MPIDR Working Paper WP 2004-008. Rostock: Max Planck Institute for Demographic Research.

Kreyenfeld, Michaela / Spieß, Katharina C. / Wagner, Gert G. (2002): Kinderbetreuungspolitik in Deutschland. Möglichkeiten nachfrageorientierter Steuerungs- und Finanzierungsinstrumente. In: Zeitschrift für Erziehungswissenschaften, vol. 5, no. 2, pp. 201-221.

Langan, Mary / Ostner, Ilona (1991): Geschlechterpolitik im Wohlfahrtsstaat: Aspekte im internationalen Vergleich. In: Kritische Justiz, pp. 302-317

Le Goff, Jean Marie (2002): Cohabiting unions in France and West Germany: Transitions to first birth and first marriage. MPIDR Working Paper WP 2002-025. Rostock: Max Planck Institute for Demographic Research.

Lessenich, Stephan / Ostner, Ilona (1995): Die institutionelle Dynamik „dritter Wege” - Zur Entwicklung der Familienpolitik in „katholischen“ Wohlfahrtsstaaten am Beispiel Deutschlands und Frankreichs. In: Zeitschrift für Sozialreform, no. 47, pp. 780-803.

Mincer, Jacob / Polachek, Solomon (1982): Family Investments in Human Capital: Earnings of Women. In: Journal of Political Economy, vol. 2, pt. 2, p. 76-108.

Ní Bhrolcháin, Máire (1986): Women's paid work and the timing of births. Longitudinal Evidence. In: European Journal of Population, vol. 2, pp. 43-70. 
Oláh, Livia Sz. (1996): The impact of public policies on the second-birth rates in Sweden: A gender perspective. Stockholm Research Reports in Demography, no. 96, Stockholm: Stockholm University.

Reuter, Silke (2002): Frankreichs Wohlfahrtsstaatsregime im Wandel? Erwerbsintegration von Französinnen und familienpolitische Reformen der 90er Jahre. ZeS-Arbeitspapier, No. 12, Bremen: Zentrum für Sozialpolitik.

Schwarz, Karl (2001): Bericht 2000 über die demographische Lage in Deutschland. In: Zeitschrift für Bevölkerungswissenschaft, vol. 26, no. 1, pp. 3-54.

Sell, Stefan (2002): "Bedarfsorientierte" Modernisierung der Kinderbetreuungsinfrastruktur in Deutschland. In: WSI Mitteilungen, no. 3, pp. 147-153.

Toulemon, Laurent (2001): How many children and how many siblings in France in the last century? Population \& Sociétés, no. 374, Paris: INED.

Toulemon, Laurent / de Guibert-Lantoine, Catherine (1998): Fertility and family surveys in countries of the ECE Region: Standard Country Report France. New York and Genf: United Nations. 


\section{Appendix}

Table 1: Number of cases included and excluded from the analysis. West German female cohort 195272

\begin{tabular}{|l|l|}
\hline number of respondents after cleaning the data set & (4, \\
\hline number of respondents with one or more children & 1,336 \\
\hline \multicolumn{1}{|c|}{ Excluded cases } & \\
\hline twins at first birth & 10 \\
\hline adopted children & 4 \\
\hline stepchildren & 15 \\
\hline fosterchildren & 6 \\
\hline first child born before the $14^{\text {th }}$ birthday of respondent & 3 \\
\hline respondent older than age 45 at first or second birth & - \\
\hline first child died before the birth of the second child & 2 \\
\hline first child born in month of interview & 3 \\
\hline absolute number of excluded cases & 43 \\
\hline & \\
\hline number of respondents & 1,293 \\
\hline number of second births & 751 \\
\hline
\end{tabular}

Table 2: Number of cases included and excluded from the analysis. French female cohort 1944-73 (unweighted)

\begin{tabular}{|l|l|}
\hline number of respondents after cleaning the data set & 2,932 \\
\hline number of respondents with one or more children & 2,189 \\
\hline \multicolumn{1}{|c|}{ Excluded cases } & \\
\hline twins at first birth & 18 \\
\hline adopted children & 4 \\
\hline stepchildren & 20 \\
\hline foster children & 13 \\
\hline first child born before the 14 birthday of respondent & 2 \\
\hline respondent older than age 45 at first or second birth & 64 \\
\hline first child died before the birth of the second child & - \\
\hline first child born in month of interview & 5 \\
\hline absolute number of excluded cases & 126 \\
\hline & \\
\hline number of respondents & 2,063 \\
\hline number of second births & 1,400 \\
\hline
\end{tabular}

\footnotetext{
${ }^{4}$ Some cases were deleted before the start of the analysis, for example cases with missing data on the year of birth of the respondents or of the first child. Also, births that appeared in an illogical order (second child born before the first child) did not enter into the analysis. We assume that these errors are randomly distributed and that therefore the results are not biased systematically.
} 
Figure 3: Education finished before the birth of the first child. Distribution of West German and French women $(n=1,293$ and $n=2,063)$

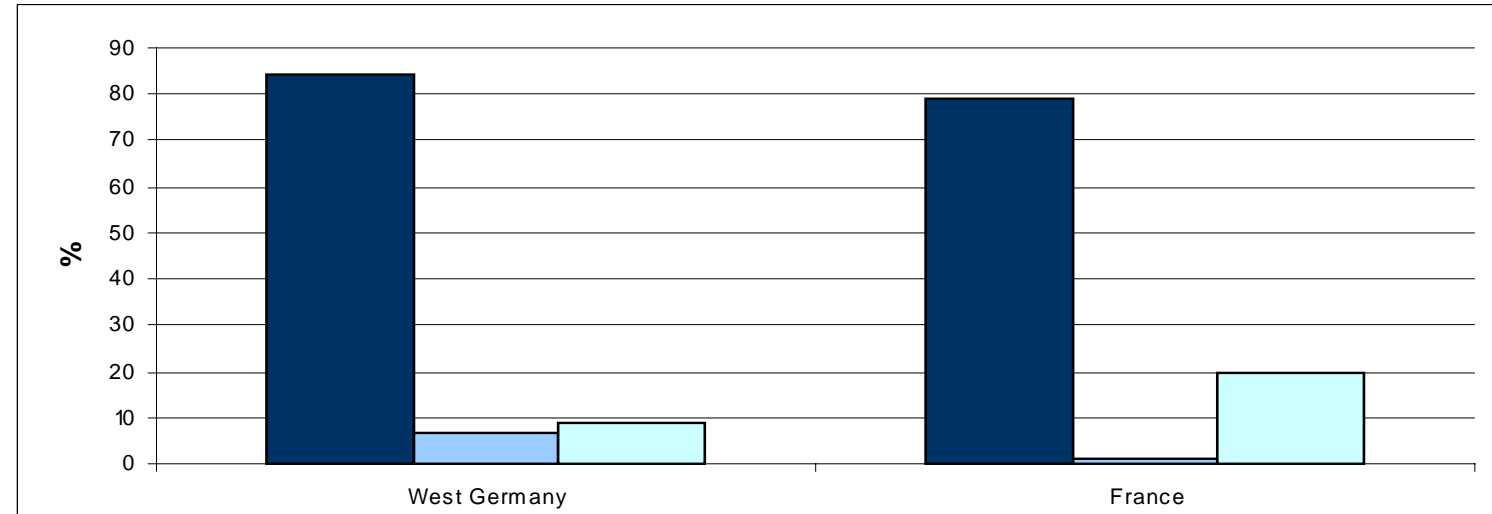

finished before first birth $\square$ finished after first birth $\square$ missing or leaving school before age 15

Source: West German FFS (1992), French FFS (1994)

Figure 4: Educational homogamy in West Germany. West German women cohort 1952-72 with at least one child $(n=1,293)$

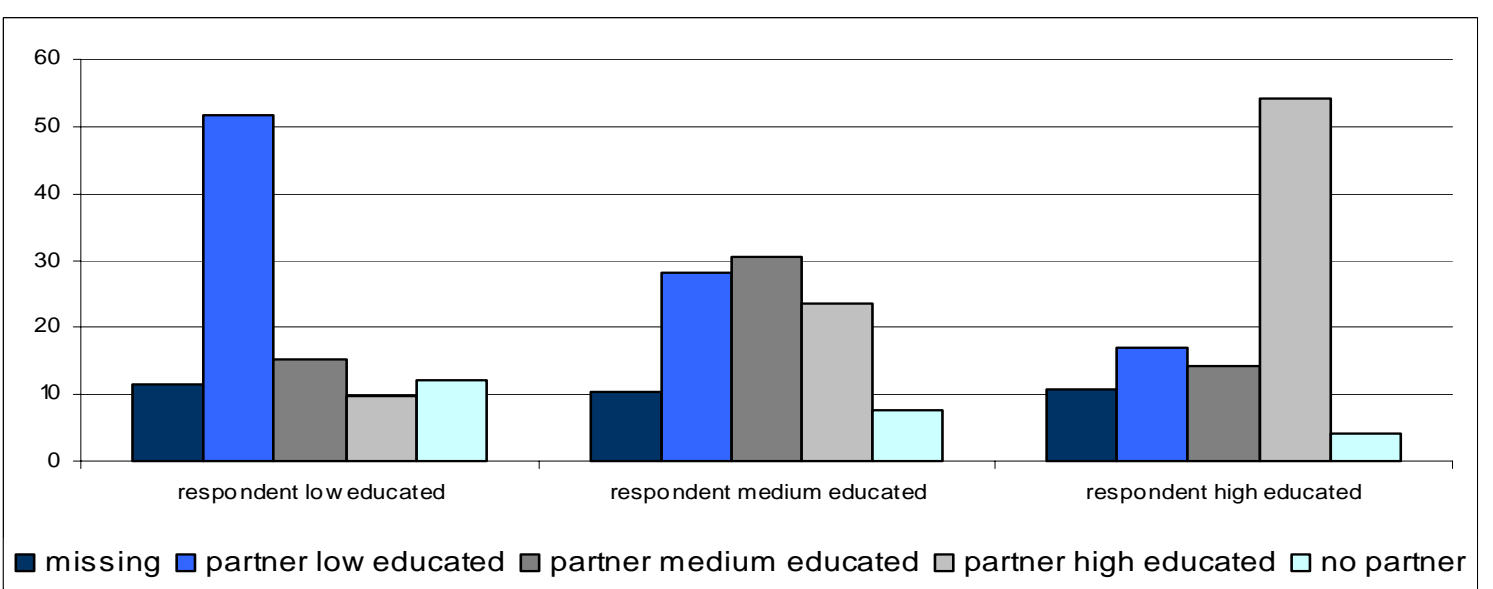

Source: West German FFS 1992

Figure 5: Educational homogamy in France. French women cohort 1944-73 with at least one child $(n=2,063)$

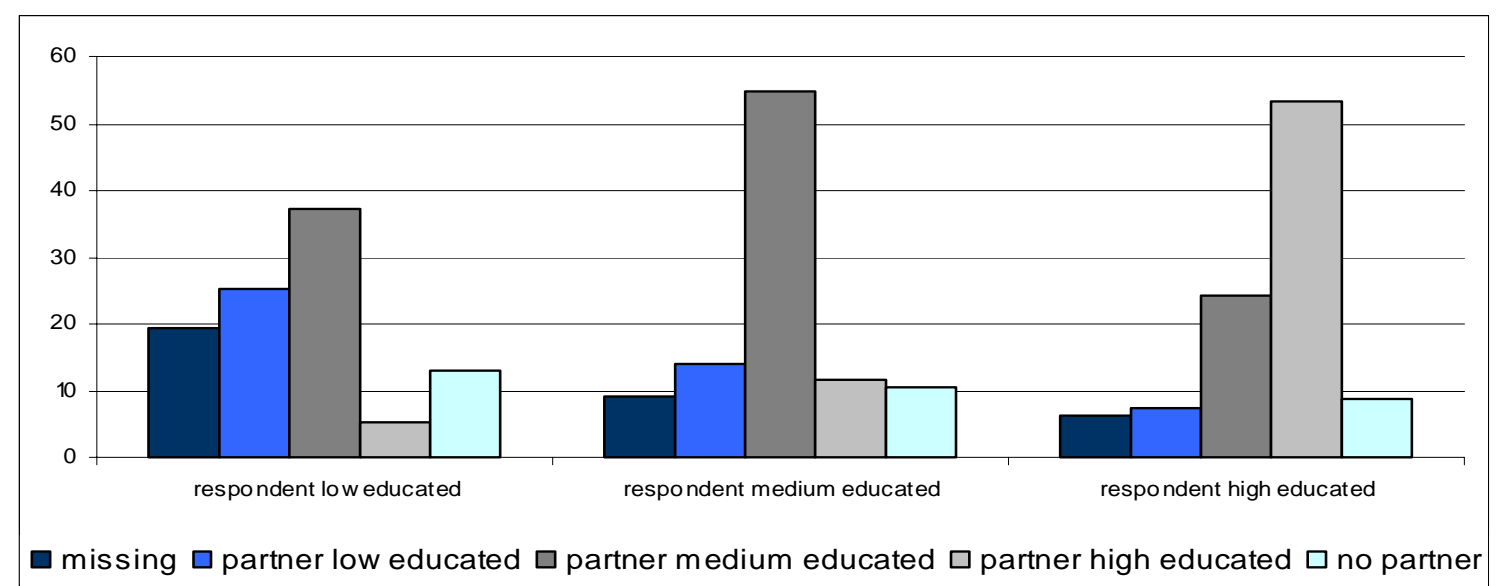

Source: French FFS 1994 